Dmytro Dymydyuk (Lviv)

(iD) https://orcid.org/0000-0001-5067-5530

\title{
The Relief on the Door of the Msho Arakelots Monastery (1134) as a Source for Studying Arms and Armour of Medieval Armenian Warriors ${ }^{1}$
}

The history of swords [weapons] is the history of humanity (R.F. Burton) ${ }^{2}$

\section{Introduction}

7 he Bagratid Kingdom of Armenia (884/886 3 -1045/1064 $)$ was the first inde1 pendent Armenian state in the Middle Ages. Having been under the control of the Persians and Umayyad Arabs for centuries, the Royal House of Bagratid was finally able to secure their independence from Arabs at the end of the $9^{\text {th }}$ century. Located at the frontier, between Eastern Roman Empire and the Muslim world, Armenia faced encroachment from both sides, but, on the other hand, adopted the best military solutions from both sides, creating its own military culture.

After the fall of the Bagratid Armenia in the middle of the $11^{\text {th }} \mathrm{c}$., the Armenian territory was under the rule of the Seljuk Turks. One of the Turks' principalities was founded in Western Armenia after the Battle of Manzikert (1071) and called ShahArmenia $(1100-1207)^{5}$, whose capital city was Ahlat, located on the north-western

\footnotetext{
${ }^{1}$ I would like to express my gratitude to Professor Valery Yotov from Varna Museum (Bulgaria) for his ideas and materials, which enabled me to prepare the present paper. Furthermore, I would like to thank Calouste Gulbenkian Foundation for a travel grant (2018), which allowed me to find necessary books in the libraries of Armenia and helped me to finish this article.

${ }^{2}$ R. Burton, The Book of the Sword. A History of Daggers, Sabers, and Scimitars from Ancient Times to the Modern Day, New York 2014.

${ }^{3}$ Note that due to the inaccuracy of the source base, modern historians (Arsen Shahinian and Cyril Toumanoff) believe that the coronation of the first Bagratid king Ashot I could have taken place between 884 and 886. - А. ШАгинян, Расформирование арабской провинции Арминийа во второй половине IX века, ВСПУ.И 2, 2009, p. 217-218; С. Toumanoff, Caucasia and Byzantium, Т. 27, 1971, p. 123-128.

${ }^{4}$ Some of the Armenian medieval chroniclers identified the fall of the Bagratid kingdom not with the Byzantine conquest of the Ani in 1045, but with Seljuks conquest in 1064. - Р. Матевосян, Падение Багратидского изарства по данньм армянских историков XI-XIII в., L২9. 10, 1988, p. 64-72.

${ }^{5}$ R. Bedrosian, Armenia during the Seljuk and Mongol Periods, [in:] The Armenian People from Ancient to Modern Times, vol. I, ed. R. Hovannisian, New York 1997, p. 241-271.
} 
shore of Lake Van. This Armeno-Turk kingdom promoted religion tolerance ${ }^{6}$ so the Armenians were able to develop their own culture. An example of this is the door from the Msho Arakelots monastery $\left(11^{\text {th }} \mathrm{c}\right.$.), which was installed in 1134 , as evidenced by the inscription it bears $-h p .<$. G29. GU SP Annnu hu 9.phqn tis 2.nцluи 9. $\delta^{7}$ [In the year 1134, D. Toros, Grikor, and Ghugas carved this door] ${ }^{8}$. The door of the church was made from walnut wood and ornamented by carvings of different geometrical shapes, images of animals and warriors. The height of the door is $2.02 \mathrm{~m}$ and its width is $1.42 \mathrm{~m}$.

Unfortunately, during the Armenian Genocide in 1915, the monastery was partially destroyed by Turkish soldiers and subsequently abandoned. But the door was preserved and transferred by German archaeologists to Bitlis, with a view to later moving it to Berlin'. However, in 1916, when Russian troops took control of the region, Armenian historian and archaeologist Smbat Ter-Avetisian found the door in Bitlis and brought it to the Museum of the Armenian Ethnographic Association in Tbilisi. But in the winter of 1921/1922, the door was moved to the newly founded History Museum of Armenia ${ }^{10}$ in Yerevan, which rapidly became one of the symbols of Armenian Genocide ${ }^{11}$.

The aim of the article is to analyse - in the context of Church and art history - the relief in the upper part of the door, where four horsemen and one infantryman with different types of arms and armours are depicted (pic. 1) $)^{12}$, and to identify various types of weapons and armours thanks to comparisons with the Armenian, Eastern Roman Empire and Muslim sources.

\section{Analysis of historiography and sources}

The history of the Msho Arakelots door was researched by many historians ${ }^{13}$, but none of them paid attention to the weapons and armours of the warriors. Moreover, the military history of the Medieval Armenia was not the object of any historical

\footnotetext{
${ }^{6}$ S. Dadoyan, The Armenians in the Medieval Islamic World. Armenian Realpolitik in the Islamic World and Diverging Paradigms Case of Cilicia Eleventh to Fourteenth Centuries, vol. II, London 2013, p. 146-149.

${ }^{7}$ U. Uч. shusuq, Ч. Uч.

${ }^{8}$ R. Tatoyan, Mush - Churches and Monasteries, https://www.houshamadyan.org/mapottomanempire/vilayet-of-bitlispaghesh/kaza-of-moush/religion/churches.html [30 VIII 2019].

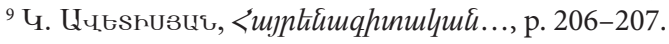

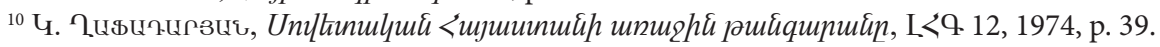

${ }^{11}$ The Door of the Arakelots (Targmanchats) Monastery in Mush, https://historymuseum.am/en/exhibitions_type/the-door-of-the-arakelots-targmanchats-monastery-in-mush/ [30 IV 2019].

${ }^{12}$ Н. СТЕПАНЯн, А. ЧАКмАКчян, Декоративное искусство средневековой Армении, Ленинград 1971, p. 51, pic. $162-163$.

${ }^{13}$ Н. СтеПАНЯн, Искусство Армении, Москва 1989, pic. 111; Н. СТЕПАНЯн, А. ЧАКМАКчян, Деко-

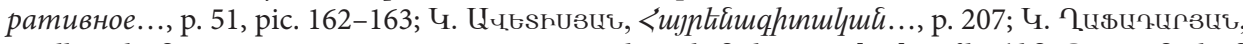

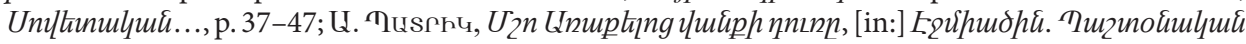

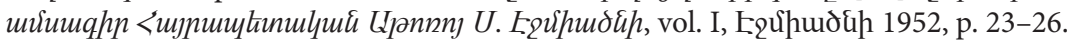


research for a long time. A few years ago, Armenian historian Karine Voskanyan defended a dissertation on the military organization of the Bagratid era ${ }^{14}$. Voskanyan partially analysed arms and armours of the Bagratid Armenia, but in her thesis she did not use almost any graphic sources, which leaves many unresolved questions about the form and functions of the weapons of that time.

On the other hand, Byzantine and Muslim arms and armours were researched by many historians (David Nicolle ${ }^{15}$, John Haldon ${ }^{16}$, Timothy Dawson ${ }^{17}$, Ian Heath ${ }^{18}$, Shihab Al-Sarraf ${ }^{19}$, Piotr Grotowski ${ }^{20}$, Mamuka Tsurtsumia ${ }^{21}$, Ada Hoffmeyer ${ }^{22}$,

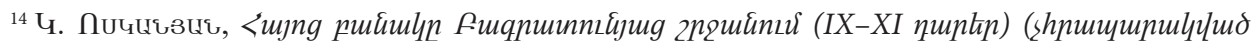

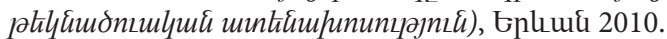

${ }^{15}$ D. Nicolle, The Military Technology of Classical Islam, vol. I-III [PhD Thesis, Edinburg 1982]; IDEM, The Armies of Islam $7^{\text {th }}-11^{\text {th }}$ Centuries, Oxford 1982; IDEM, The Cappella Palatina Ceiling and the Muslim Military Inheritance of Norman Sicily, Gla 16, 1983, p. 45-145; IDEM, Saladin and the Saracens, Oxford 1986; IDEM, Byzantine and Islamic Arms and Armour: Evidence for Mutual Influence, GA 4, 1991, p. 299-325; IDEM, Sassanian Armies. The Iranian Empire, Early $3^{\text {rd }}$ to mid- $7^{\text {th }}$ Centuries $A D$, Stockport 1996; IDEM, Armies of the Caliphates (862-1098), Oxford 1998; IDEM, Arms and Armour of the Crusading Era 1050-1350. Western Europe and the Crusader States, London 1999; IDEM, Two Swords from the Foundation of Gibraltar, Gla 22, 2002, p. 147-199; A Companion to Medieval Arms and Armour, ed. IDEM, Woodbridge 2002; IDEM, Byzantine, Western European, Islamic and Central Asian Influence in the Field of Arms and Armour from the Seventh to Fourteenth Century AD, [in:] Islamic Crosspollinations. Interactions in the Medieval Middle East, Cambridge 2007, p. 94-118; IDEM, Crusader Warfare. Muslims, Mongols and the Struggle against the Crusades, vol. II, London 2007; IDEM, Manzikert 1071. Złamanie potęgi Bizancjum, trans. M. BALICKI, Warszawa 2018.

${ }^{16} \mathrm{~J}$. HALDON, Some Aspects of Byzantine Military Technology from the $6^{\text {th }}$ to the $10^{\text {th }}$ centuries, BMGS 1 , 1975, p. 11-47; IDEM, Warfare, State and Society in the Byzantine World, 565-1204, London 1999; IDEM, A Critical Commentary on The Taktika of Leo VI, Washington 2014; IDEM, Wojny Bizancjum. Strategia, taktyka, kampanie, trans. N. Radomski, Poznań 2019.

${ }^{17}$ T. Dawson, The Myth of the "Varangian Rhomphaia": a Cautionary Tale, VaV 22, 1992, p. 24-26; IDEM, Banded Lamellar - a Solution, VaV 23, 1992, p. 16; IDEM, Kremasmata, Kabadion, Klibanion: Some Aspects of Middle Byzantine Military Equipment Reconsidered, BMGS 22, 1998, p. 38-50; IDEM, Klivanion Revisited: an Evolutionary Typology and Catalogue of Middle Byzantine Lamellar, JRMES 12/13, 2001/2002, p. 89-95; IDEM, Suntagma Hoplon: The Equipment of Regular Byzantine Troops, c. 950 to c. 1204, [in:] A Companion to Medieval..., p. 81-96; IDEM, Byzantine Infantryman. Eastern Roman Empire c. 900-1204, Oxford 2007; IDEM, Fit for the Task: Equipment Sizes and the Transmission of Military Lore, Sixth to Tenth centuries, BMGS 32, 2007, p. 1-12; IDEM, Byzantine Cavalryman c. 900-1204, Oxford 2009; IDEM, Armour Never Wearies: Scale and Lamellar Armour in the West, from the Bronze Age to the $19^{\text {th }}$ Century, Cheltenham 2013.

${ }^{18}$ I. Heath, Byzantine Armies 886-1118, Oxford 1979, p. 48; IDEM, Armies of the Dark Ages, 600-1066 $A D$, Worthing 1980, p. 128.

${ }^{19} \mathrm{~S}$. AL-SARraf, Close Combat Weapons in the Early Abbasid Period, [in:] A Companion to Medieval..., p. 149-178.

${ }^{20}$ P. Grotowsкi, Arms and Armour of the Warrior Saints. Tradition and Innovation in Byzantine Iconography (843-1261), Leiden 2010 [= MMe, 87].

${ }^{21}$ M. Tsurtsumia, The Evolution of Splint Armour in Georgia and Byzantium: Lamellar and Scale Armour in the 10 $0^{\text {th }}-12^{\text {th }}$ Centuries, Sym 21, 2011, p. 65-99; IDEM, Medieval Sword and Sabre from the Georgian National Museum, AMM 11, 2015, p. 159-172; IDEM, The Mace in Medieval Georgia, AMM 14,2018, p. 87-114.

${ }^{22}$ A. Hoffmeyer, Military Equipment in the Byzantine Manuscript of Scylitzes in the Biblioteca Nacional in Madrid, Gla 5, 1966, p. 1-160. 
Taxiarchis Kolias ${ }^{23}$, Georgios Theotokis ${ }^{24}$, Raffaele D’Amato ${ }^{25}$, Valery Yotov ${ }^{26}$, Gennady Baranov ${ }^{27}$ and others). Therefore, the best way to study the military equipment represented on the door is to compare it with the Eastern Roman and Muslim sources because Armenia was for a long time under the influence of these two Empires and accepted many military innovations from both sides.

Unfortunately, the situation with Armenian archaeological and written sources is challenging. Most archaeological artefacts of arms and armours from around the Bagratid era were poorly researched and dated too broadly $\left(9^{\text {th }}-13^{\text {th }} c\right.$.). In the Soviet era, only several historians and archaeologists (Valentina Abrahamyan ${ }^{28}$, Babken Arakelyan ${ }^{29}$,

${ }^{23}$ T. Kolias, Byzantinische Waffen. Ein Beitrag zur byzantinischen Waffenkunde von den Anfängen bis zur lateinischen Eroberung, Wien 1988 [= BV, 17].

${ }^{24}$ G. Theотокіs, Military Technology: Production and Use of Weapons, [in:] A Companion to the Byzantine Culture of War, ca. 300-1204, ed. Y. Stouraitis, Boston 2018, p. 440-473.

${ }^{25}$ R. D'Amato, The Eastern Romans 330-1461 AD, Hong Kong 2007; IDEM, The Varangian Guard 988-1453, Oxford 2010; IDEM, The Betrayal: Military Iconography and Archaeology in the Byzantine Paintings of XI-XV Centuries AD Representing the Arrest of Our Lord, [in:] Weapons Bring Peace? Warfare in Medieval and Early Modern Europe, ed. L. MAREK, Wrocław 2010, p. 69-95; IDEM, $\Sigma 1 \delta \eta-$

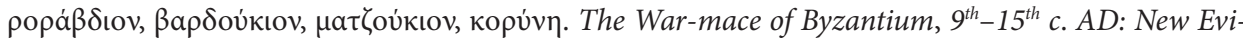
dence from the Balkans in the Collection of the World Museum of Man, Florida, AMM 7, 2011, p. 7-48; IDEM, Byzantine Imperial Guardsmen, 925-1025, Oxford 2012; IDEM, Old and New Evidence on the East-Roman Helmets from the 9 to the 12 Centuries, AMM 11, 2015, p. 27-157.

${ }^{26}$ В. Йотов, Въоръжението и снаряжението от българското средновековие (VII-XI век), Варна 2004; іDEм, Перекрестье меча из Херсонеса, АДСВ 39, 2009, р. 251-261; іDем, Ранние сабли (VIII-X вв.) на Нижнем Дунае, [in:] Культуры Евразийских степей второй половины I тысячелетия н.э, Самара 2010, p. 217-225; V. Yoтоv, Byzantine Time Swords (10-11 c.), SUC I, 2011, p. 35-45; IDEM, A New Byzantine Type of Swords ( $7^{\text {th }}-11^{\text {th }}$ Centuries), [in:] Niš and Byzantium, vol. IX, Niš 2011, p. 113-124; IDEM, The Kunagota Sword Guard and the Dating of Two Bronze Matrices for Hilt Manufacturing, [in:] Die Archäologie der frühen Ungarn, Mainz 2012, p. 219-226; IDEM, Byzantine Weaponry and Military Equipment in the Homilies of St Gregory of Nazianzus (Paris, Gr. 510), FAH 30, 2017, p. 153-163.

${ }^{27}$ Г. БАРАНОв, Болгаро-византийское навершие рукояти сабли с территории Северо-Восточного Причерноморья, МАИАСК 6, 2014, р. 84-93; ІDЕм, Новая находка перекрестья и навершия рукояти византийского меча с территории Черкасского района Черкасской области Украины, МАИАСК 7, 2015, р. 87-105; IDEм, Находки раннесредневековых сабель "Болгарского типа» в бассейне верхнего и среднего течения Днестра, МАИАСК 8, 2016, р. 76-92; IDЕМ, Византийские (средиземноморские) мечи с перекрестьями с мубтой IX-ХІ вв., МАИАСК 9, 2017, p. 248-283; IDEм, Византийский меч с территории Украины, [in:] Война и оружие. Новые исследования и материаль, pars 1, Санкт-Петербург 2017, p. 171-177; IDEм, Перекрестье меча из раскопок византийского Херсона, ВА 4, 2018, р. 31-42.

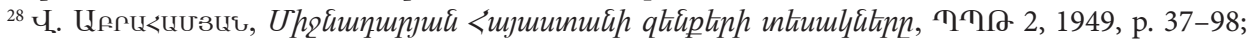

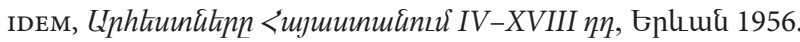

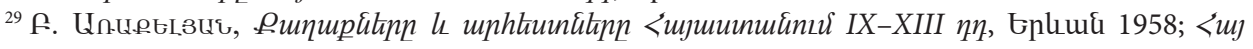

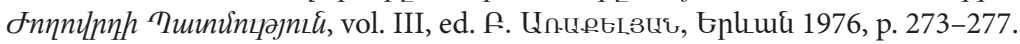


Aram Kalantaryan ${ }^{30}$ and others ${ }^{31}$ ) published pictures of separate archaeological findings which were located in the History Museum of Armenia. Unfortunately, almost all of these pictures presented the artefacts redrawn in two dimensions only, and were not accompanied by photographs or information about the artefacts' measurements, materials, etc. On the other hand, Armenian written sources are less useful for the study of the material military culture because they give only general information about weapons and armour without a detailed description. Moreover, many unresolved terminological problems concerning the names of the weapons and armours have remained.

However, Armenian figurative sources were researched much better. For example, Armenian miniatures $\left(10^{\text {th }}-14^{\text {th }} \mathrm{c}\right.$.) have been thoroughly analysed by some art historians (Tetiana Izmailova ${ }^{32}$, Dickrana Kouymjian ${ }^{33}$, Sirarpie Der Nersessian $^{34}$ and others). What is more, D. Kouymjian published dozens of photos of Armenian miniatures $\left(10^{\text {th }}-14^{\text {th }} \mathrm{c}\right.$.) on the website of the University of Fresno and the University of Hamburg ${ }^{35}$. Also, no less important are the reliefs on the Cathedral of the Holy Cross on Aghtamar Island (915-921) (pic. 5), where some Biblical characters with arms and armours $^{36}$ are depicted. Unfortunately,

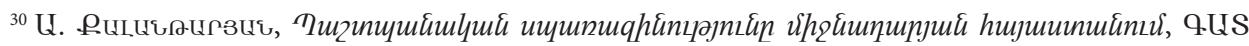

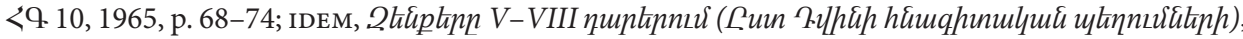

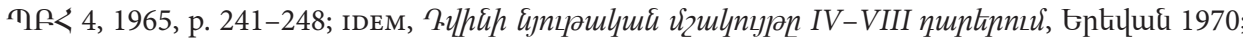

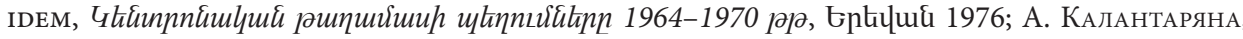
Двин. Город Двин и его раскопки (1981-1985), vol. IV, Ереван 2008.

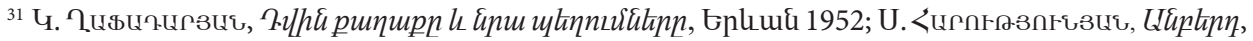

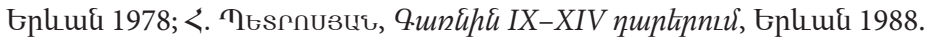

${ }^{32}$ T. Izmailova, L'Iconographie du cycle des fêtes d'un groupe de codex arméniens d'Asie Mineure, REArm 4, 1967, p. 125-166; Т. ИзмайловА, Армянская миниатюра ХІ века, Ереван 1979.

${ }^{33}$ D. Kouymjian, The Evolution of Armenian Gospel Illumination: The Formative Period $\left(9^{\text {th }}-11^{\text {th }}\right.$ Centuries), [in:] Armenian and the Bible. Papers Presented to the International Symposium Held at Heidelberg, July 16-19, 1990, ed. C. Burchard, Atlanta 1993, p. 125-142; IDEM, The Art of the Book: Armenian Medieval Illumination, [in:] Armenia. Imprints of a Civilization, ed. G. UluHoGian, B.L. Zekiyan, V. Karapetian, Milan 2011, p. 89-123; IDEM, The Melitene Group of Armenian Miniature Painting in the Eleventh Century, [in:] R.G. Hovannisian, Armenian Kesaria/Kayseri and Cappadocia, Costa Mesa 2013, p. 79-115.

${ }^{34}$ S. Der Nersessian, The Date of the Initial Miniatures of the Etchmiadzin Gospel, EBA 1, 1973, p. 535-538; IDEM, An Introduction to Armenian Manuscript Illumination, Selections from the Walters Art Gallery, Baltimore 1974; IDEM, Armenian Art, London 1978; IDEM, L'Evangile du roi Gagik de Kars: Jérusalem No 2556, REArm 18, 1984, p. 85-107; IDEM, Miniature Painting in the Armenian Kingdom of Cilicia from the Twelfth to the Fourteenth Century, vol. I, Washington 1993.

${ }^{35}$ Index of Armenian Art: Database of Armenian Manuscript Illuminations, https://mycms-vs04.rrz. uni-hamburg.de/sfb950/content/IAA/browseColl.xml [30 IV 2019].

${ }^{36}$ J. Davies, Medieval Armenian Art and Architecture. Church of the Holy Cross, Aght'amar, London 1991; S. Der Nersesian, Aght'amar. Church of the Holy Cross, Cambridge 1965; И. Орьели, 
very few historians paid special attention to the arms and armours presented on miniatures or reliefs ${ }^{37}$.

For the first time in Armenian historiography, weapons will not be the subject but the object of research, where - in the context of Church and art history - the issues of armament of medieval Armenian warriors will be analysed in comparison with Eastern Roman and Muslim samples, in an attempt to make this study more relevant ${ }^{38}$.

\section{Analysis of relief}

The relief in the upper part of the door from the Msho Arakelots monastery can be provisionally divided into three parts ${ }^{39}$ : in the left part, there are two heavily armoured horsemen (azats) ${ }^{40}$, one of whom is trying to escape, while the other pierces him through with a sword. In the middle of the relief, there is an infantryman with a trumpet and on the right side two light horsemen are presented, one of whom is piercing through a big snake or a dragon with his spear. The height of these figures is approximately $17 \mathrm{~cm}$.

Armenian historian Kamsar Avetisian thought that this relief depicts non-religious, historical scenes ${ }^{41}$, but this is not completely true. Let us pay attention to the inscription on the right side of the relief, which $\mathrm{K}$. Avetisian reads as $L A q \cap \Omega \mathrm{Q}$. [ABGORG]. He thinks that this word was randomly added in later centuries (or that the author made some mistake? ${ }^{42}$. However, if the word is given an alternative reading of $U \rho Q[k] \cap \rho Q$. [SB G[E]ORG], the outcome is "St. George", which can be accurate because under this description there is a horseman spearing a dragon

Избранные труды, vol. I, Москва 1968; L. Jones, Between Islam and Byzantium, Aldershot 2007; IDEM, The Visual Expression of Power and Piety in Medieval Armenia: The Palace and Palace Church at Aghtamar, [in:] Eastern Approaches to Byzantium, Aldershot 2001, p. 221-241; The Church of the Holy Cross of Att'amar, ed. Z. Pogossian, E. Vardanyan, Leiden 2019, p. 460.

${ }^{37}$ A notable exception is a recent study by English scholars I. Heath and D. Nicolle, who based their visive reconstructions of the medieval Armenian warriors on the Aghtamar reliefs and other sources. See for instance: I. Heath, Armies of the Dark..., figs. 91-92, p. 100-101; D. Nicolle, Armies of the Caliphates..., plate A2, p. 45.

${ }^{38}$ Note that some types of weapons or armours depicted are presented schematically. Therefore, only some suggestions as to how to interpret them will be offered.

${ }^{39}$ Based on the two inscriptions on the relief (which will be discussed below) and the visual position of the figures, it could be assumed that at least two separate "scenes" were presented on the relief (in the right and left corners). Unfortunately, it cannot be stated with certainty whether the middle part of the relief ("infantryman with a trumpet") is related to the "scenes" on the left or the right. Therefore, a third part has been posited by this study.

${ }^{40}$ Armenian azats were equivalent to heavy armoured Byzantine cataphracts.

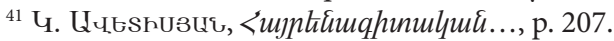

${ }^{42}$ Ibidem, p. 207-208. 
(it is a traditional religious iconography in the Late Roman and Orthodox art) ${ }^{43}$. Note, for instance, similar depictions of St. George killing the dragon with his spear present in Georgian (pic. 6) ${ }^{44}$ and Armenian art (pic. 7) ${ }^{45}$.

In the left corner of the relief, there is a partial inscription but it is poorly pre-

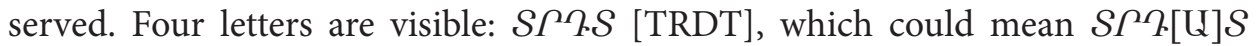
$\left([\mathrm{TRD}[\mathrm{A}] \mathrm{T}-\text { Tiridates - an Armenian name })^{46}\right.$. Arakel Patrick suggests that this scene was an episode from the Armenian national epic Daredevils of Sassoun $\left(8^{\text {th }}-13^{\text {th }}\right.$ c. $)$, in which David, riding on a horse, is pursuing Msra-Melik, but no definitive answer is provided. Patrick also believes that these inscriptions were added later ${ }^{47}$.

\section{Left part of the relief (pic. 2)}

\section{Sleeve cross-guard}

Here, two men on horseback are visible, one of whom is trying to escape while the other pierces him through with a sword ${ }^{48}$. The sword depicted consists of the edge, grip, pommels, cross-guard and a wide part above the cross-guard, which is called sleeve (pic. 2:1). Bulgarian historian V. Yotov aptly remarked that the typology of swords is often a typology of the sword-guards ${ }^{49}$. Indeed, the relief includes a representation of one type of sleeve cross-guard present in Armenian art, which is not unlike the type visible on the interior fresco Massacre of the Innocents in the Aghtamar Church ${ }^{50}$.

\footnotetext{
${ }^{43}$ A. Patrick is of the same opinion but he suggests two interpretation of this inscription: "Uค qחPQ"

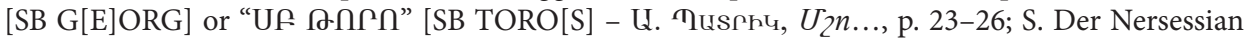
reads the right-hand side inscription as "Theodore" - S. Der Nersessian, Armenian Art..., p. 205. ${ }^{44}$ St. George and St. Theodore slaying dragons. Relief from the Church in Martvili, $7^{\text {th }}-8^{\text {th }} c$. (Georgia). - Г. Атанасов, Св. Георги Победоносеи. Култ и образ в Православния Изток през средновековието, Варна 2001, pic. 244. For more information about representations of Saint George in Medieval art, see C. WALTER, The Origins of the Cult of Saint George, REB 53, 1995, p. 295-326; IDEM, The Warrior Saints in Byzantine Art and Tradition, Aldershot 2003, p. 109-144; Г. АтАнAсов, Войнските иконографии, въоръжението и снаряжението на свети Георги през ранното средновековие (V-X в.), [in:] Acta Musei Varnensis, I, Оръжие и снаряжение през късната античност и средновековието IV-XV в., ed. В. Йотов, Варна 2002, p. 35-55. Information courtesy of Yanko Hristov.

${ }^{45}$ Gospel, Mekhitarian Library, Ms. 697, f. 4 v.

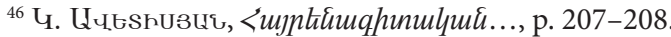

${ }^{47}$ U. Tusshu, $U_{2}$ n..., p. 23, 25-26.

${ }^{48} \mathrm{~S}$. Der Nersessian thought that this is spear but it is not true - S. Der Nersessian, Armenian Art..., p. 205. However, at that time, cavalrymen preferred a cut attack rather than a thrust, as it is presented on the relief, because of the difficulty of dealing a thrusting punch while on horseback. Perhaps this is why S. Der Nersessian suggested that the relief depicts a spear.

${ }^{49}$ V. Yotov, A New Byzantine..., p. 115.

${ }^{50}$ I have this information courtesy of Dr D'Amato, who, having obtained the authorization from the Turkish government, will soon publish the results of this discovery.
} 
The swords with the sleeve cross-guards are one of the "Byzantine" 51 types of swords which were identified and researched by G. Baranov ${ }^{52}$ and V. Yotov" These types of cross-guards were popular in the $9^{\text {th }}-11^{\text {th }} \mathrm{C}$. in Eastern Europe, Balkan Peninsula and the Middle East ${ }^{54}$.

Sleeve cross-guards were created in order to protect the joint between the edge and the hilt from breaking ${ }^{55}$. According to another theory, the appearance of the sleeve cross-guards was connected with the way of gripping (the so-called "Italian grip"), whereby the index finger was placed on a cross-guard ${ }^{56}$, which allowed more efficient fencing ${ }^{57}$.

Sleeve cross-guards are divided into several types, two of which are relevant for this study, being the most similar to the one presented on the relief of the door of the Msho Arakelots monastery: they are "Galovo" and "Pliska-48"

Specimens of "Galovo" and "Pliska-48" cross-guards were found in Bulgaria, Serbia, Ukraine, Syria, Arabian Peninsula, Egypt etc. ${ }^{59}$ (pic. $\left.8-10\right)^{60}$. Moreover,

${ }^{51}$ The Romans in the Middle Age, now conventionally referred to as the "Byzantines", borrowed many types of weapons from neighbouring states, and consequently it is not possible to determine beyond all doubt which types of swords were created by the Byzantines. The term "Byzantine swords" can be used conventionally to indicate a type of sword produced inside the Eastern Roman Empire. The origin of swords with sleeve cross-guards is unknown. - С. КАмьуров, "Арабски" ранносредновековни мечове в днешните български земи", Ист 25, 3, 2017, p. 271; R. D’Амато, Byzantine Imperial..., p. 5, 43-44.

${ }^{52}$ Г. БАРАНОВ, Византийские..., p. 248-283, etc.

${ }^{53}$ V. Yotov, A New Byzantine..., p. 113-124; IDEм, Byzantine Time..., p. 35-46; IDEM, Въоръжениemo..., p. 39-41, etc.

${ }^{54}$ It needs to be noted that two cross-guards from Syria were displayed in public only once, at an auction, where for some reason they were dated to the $12^{\text {th }}-13^{\text {th }} \mathrm{c}$. Their subsequent fortunes are unknown. - Г. БАРАНов, Византийские..., p. 255-256.

${ }^{55}$ Ibidem, p. 251, 265.

${ }^{56}$ D. Nicolle, Byzantine and Islamic..., p. 305.

${ }^{57}$ Note that the "Italian grip" existed already in the times of the Sasanid Iran. - K. FarrokH, G. KARAmian, K. Maksymiuk, A Synopsis of Sasanian Military Organization and Combat Units, SiedlceTehran 2018, p. 35-36, fig. 32-34.

${ }^{58}$ Unfortunately, it is unclear which of these two types best match the sword depicted on the relief, because they are both similar and the sword on the relief is presented too schematically. I would like to express my gratitude to V. Yotov for useful advice.

${ }^{59}$ S. Al-Sarraf, Close Combat..., pic. XII-40; M. Aleksić, Some Typological Features of Byzantine Spatha, ЗРВИ 47, 2010, p. 121-138; D. RAвоvyanov, Early Medieval Sword Guards from Bulgaria, АВu 2, 2011, p. 82; В. Йотов, Въоръжението..., р. 39-41; Г. БАРАНОВ, Византийские..., p. 255-256, 274-280; С. КАмьуров, “Арабски”..., p. 269-270, 276, 285, 289; I. Norman, A Likely Byzantine or Fatimid Sword of the $X^{\text {th }}-X I^{\text {th }}$ Centuries, 2019, http://iainnorman.com/essays/2019/01/ a-likely-byzantine-or-fatimid-sword-of-the-xth-xith-centuries/ [30 IV 2019] (pic. 9-10); Sleeve cross-guard. Unpublished archaeological find from Chernihiv, Ukraine (2018). Finding of grave robbers, https://vk.com/vtoroi_rim?w=wall-71532966_3071\%2Fall [30 IV 2019] (pic. 8).

${ }^{60}$ Most of these sleeve cross-guards were described by the aforementioned historians. Therefore, only the photos of two most recent archaeological finds, which at the moment are little-known in historiography, will be presented here. 
they are visible on Eastern Roman miniatures such as the one from the Theodore Gospel (1066) (pic. 11) ${ }^{61}$ and the Menologion of Basil II (end of the 10 $0^{\text {th }} \mathrm{c}$.) (pic. 12,31$)^{62}$.

It is interesting to note that the physical characteristics of the sword with a sleeve cross-guard are known thanks to archaeological discoveries. As regards the swords on pic. 9-10, the overall length of the sword is $83.4 \mathrm{~cm}(71.2 \mathrm{~cm}$ being the size of the blade only). The blade is $6.4 \mathrm{~cm}$ wide and $0.51-0.57 \mathrm{~cm}$ thick. The hilt is $12.3 \mathrm{~cm}$ long, and the cross-guard is $12.9 \mathrm{~cm}$ wide and $1.59 \mathrm{~cm}$ thick. The sleeve is $3.76 \mathrm{~cm}$ wide. The pommel is $3.99 \mathrm{~cm}$ wide, $6.06 \mathrm{~cm}$ long and $1.39 \mathrm{~cm}$ thick. The weight of the sword is apprx. $1 \mathrm{~kg}^{63}$.

Thanks to this depiction of a sleeve cross-guard in the Armenian art, it can be assumed that such types of cross-guards existed in Armenia even before (in $10^{\text {th }}-11^{\text {th }} \mathrm{c}$., based on the dating of the abovementioned archaeological finds from Eastern Europe and on the Aghtamar Church images). Furthermore, such sleeve cross-guards were likely employed in the subsequent periods (in the $12^{\text {th }} \mathrm{c}$.) and at other locations, including the territory of the South Caucasus region.

\section{Mace with spherical head}

The first warrior, who is trying to escape, is holding in his right hand a mace with a spherical head (pic. 2:2) ${ }^{64}$. Maces were used as a heavy weapon by cavalrymen and infantrymen in order to break helmets or heavy armour ${ }^{65}$. The mace consisted of two parts: the mace head (weighing approx. 200-300 g), and a wooden or iron stick (50-60 cm long) ${ }^{66}$.

R. D'Amato believes that these maces were originally imported from India or Persia or had Eastern origins ${ }^{67}$, but soon became popular in Byzantium. Arkadiusz Michalak also wrote that spherical maces (type $\mathrm{V}$ according to his typologization) were popular in Eastern Europe as well (Kievan Rus' and the Baltic region) ${ }^{68}$.

${ }^{61}$ Theodore Gospel, British Library, Ms. 19352, f. 191.

${ }^{62}$ Menologion of Basil II, Vatican Library, Ms. Vat. gr. 1613, f. 135. Note that under the typology of Byzantine swords suggested by T. Dawson (which was based on the miniatures of Basil's Menologion), the sleeve cross-guard was presented under number 2. - T. DAwson, Byzantine Cavalryman..., p. 5 .

${ }^{63}$ I. NoRman, A Likely... Other uncovered swords and sleeve cross-guards have similar characteristics. The only difference is that some sleeve cross-guards were broader $(13-15 \mathrm{~cm})$. - Г. БАРАНОВ, Византийские..., p. 255-256, 274-280.

${ }^{64}$ The round head maces could be plain, toothed, spiked or flanged. Presented on the relief is the plain (spherical) type of round head maces. Also, polygonal head maces existed in Armenia.

${ }^{65}$ D. Nicolle, The Military..., p. 68.

${ }^{66}$ А. Кирпичников, Древнерусское оружие, vol. II, Москва-Ленинград 1966, p. 53.

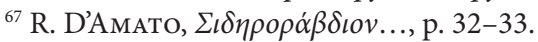

${ }^{68}$ A. Michalak, Wplywy wschodnie czy południowe? Z badań nad pochodzeniem buław średniowiecznych na ziemiach polskich, ВНУЛП 571, 2006, p. 57-59, 64. Note that in the most famous 
The same types of maces were found in Bulgaria and dated to $10^{\text {th }}-11^{\text {th }} \mathrm{c}$. (pic. 13 , $14 \mathrm{a}, 14 \mathrm{~b})^{69}$; on miniatures in the Homilies of St. Gregory of Nazianzus (879-883) (pic. 15) $)^{70}$, Oppianus Cynegetica $\left(11^{\text {th }}\right.$ c.) (pic. 16) ${ }^{71}$ and even on Armenian miniatures $\left(10^{\text {th }}-11^{\text {th }} \text { c.) (pic. 17.1 }\right)^{72}$. Moreover, many depictions of round headed maces dated to $7^{\text {th }}-11^{\text {th }}$ c. were found in the Middle East (Egypt, Iraq, Iran and Syria) ${ }^{73}$.

As can be seen, the plain (spherical) type of round head maces was simple in production and popular over a large area in different times ${ }^{74}$, so nothing particular can be said about the origin of spherical maces and no connections established between specimens from Eastern Europe and Byzantium-Armenia, although the decoration of the Bulgarian maces is clearly of Eastern Roman origins ${ }^{75}$. A relatively simple shape of spherical maces can suggest that they were produced in local workshops (by casting or forging) ${ }^{76}$, in different cultural regions, independently of each other ${ }^{77}$. For example, there are similar maces among archaeological finds from the times of Ancient Armenia (pic. 18) ${ }^{78}$.

\section{Armour}

Both warriors in the left corner are armoured (pic. 2). Visible on the bodies of the warriors is what seems to be a chain mail, which looks like a sweeter with long sleeves. Also, on the chest and lower torso, small iron or bronze rectangular plates

typology of maces from Kyivan Rus and Eastern Europe, suggested by A. Kirpichnikov, there are no maces with spherical heads. - A. Кирпичников, Древнерусское оружие..., pic. 10.

${ }^{69}$ S. Popov, The Maces from the Present Bulgarian Lands (10 $0^{\text {th }}-17^{\text {th }}$ c.), Sofia 2015, p. 130-131; В. Йотов, Въоръжението..., cat. 644. Idea courtesy of V. Yotov.

${ }^{70}$ Homilies of St. Gregory of Nazianzus, National Library of France, gr. 510, f. 143.

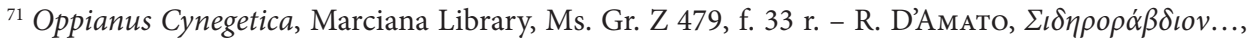
fig. 17.

${ }^{72}$ Melitene Gospel, Matenadaran, Ms. 3784, f. 9; Jerusalem Gospel, Jerusalem Armenian Patriarchate, Ms. 3624, f. 9; Areg Gospel, Areg village (in situ) - D. Kouymjian, The Melitene..., fig. 20. I am currently working on a separate article about arms and armours on the Armenian miniatures from the $10^{\text {th }}-11^{\text {th }} \mathrm{c}$., where this topic will be researched in greater detail. Therefore, in this article, I only present one miniature which features the best example of a spherical mace.

${ }^{73}$ S. Al-Sarraf, Close Combat..., XII - 48, 49, 50, 54, 57b.

${ }^{74}$ В. БЕРЕЖИнСьКИй, Зброя Київської Русі. Булава, Київ 1998, р. 7.

${ }^{75} \mathrm{M}$. Tsurtsumia wrote that according to written sources two types of mace were used in Georgia (and in Armenia too): the "lakhti" [jupun] (flanged mace) and the "gurz" [qnınq] (a mace with a rounded head), which had their own types (spiked, knobbed etc.). Both these terms come from the Persian names of this weapon -"lakht" and "gorz". For more information on the topic, see M. TsuRTsumia, The Mace..., p. 88-91; S. Al-Sarraf, Close Combat..., p. 152-160.

${ }^{76}$ For more information on the production of iron and bronze maces, see А. Кирпичников, Древнерусское оружие..., р. 52.

${ }_{77}$ М. Козак, Булава як елемент озброєння Галицького та Волинського князівств у XI-XIV століттях, [in:] Проблеми історії війн і військового мистеитвва, еd. Л.В. ВойтовичА, Львів 2018, p. 58-59. I would like to express my gratitude to Mykola Kozak for useful advice.

${ }^{78}$ С. ЕСАЯн, Оружие и военное дело древней Армении (III-I тыс. до н. э.), Ереван 1966, р. 51-56. 
laced into horizontal rows are presented. This may be a lamellar armour, which only covered the torso and was worn on the chain mail. It was one of the best types of armour in Byzantium and Arab Caliphate at that time.

In a number of cases, it is rather difficult to tell the difference between lamellar and scale armour, especially when analysing graphic sources ${ }^{79}$. Lamellar armour consists of rectangular plates, linked with one another first in horizontal rows, then vertically by means of thongs passed through holes. No less popular was the scale armour, which was different in that its plates had mainly an oval form and were attached to each other and to the backing of the cloth or leather, in overlapping rows (like fish scale) (pic. 20-21) ${ }^{80}$. The weight of the scale and lamellar armour was almost the same. A complete set of armour 1-1.5 mm thick weighs $14-16 \mathrm{~kg}$. It is $1.5-2$ times as heavy as mail ${ }^{81}$. Of course, the above-mentioned types of armours were very expensive, so only honoured warriors (called azats) could afford them ${ }^{82}$. The disadvantage of the scale armour was that the plates were raised while the rider was on a horse, which made him vulnerable to spear attacks, especially from below.

From the end of the $10^{\text {th }} \mathrm{c}$., craftsmen started using rivets (instead of laces) for fastening plates, which greatly simplified their production and improved the impact resistance of the lamellae ${ }^{83}$. This fact was mentioned by Armenian historian Hovhannes Draskhanakerttsi $\left(10^{\text {th }} \text { c. }\right)^{84}$ : ...Subsequently, in 921, king of Egrisi [Abkhazia] gave [king of Armenia] Ashot II [914-928/929] much assistance, and gathered numerous forces with winged steeds, iron-studded armour [in Russian translation: в скрепленных железными гвоздями нагрудниках ${ }^{85}$, and fearful helmets, iron-studded breastplates and strong shields... ${ }^{86}$ Most often, lamellar plates on the sleeves were much larger than in the region of the torso, because the warrior had to bend and move constantly, and the small size of the plates would not hinder

\footnotetext{
${ }^{79}$ M. Tsurtsumia, The Evolution..., p. 65; J. Haldon, Warfare, State..., p. 131-134, 220, 223.

${ }^{80}$ Gospel № 141/102, Mekhitarists Library (Venice), fol. 77 r; Theodore Gospel, Jerusalem Armenian Patriarchate, Ms. 1796, fol. 88.

${ }^{81}$ M. Tsurtsumia, The Evolution..., p. 67, 69-71.

${ }^{82}$ Some military units were dressed in the clothes of the same colour (e.g. in 988, a unit of Kars king Abas was dressed in "red uniforms"). - Всеобщая история Асохика, trans. Н. Эмина, Москва 2011, p. 182.

${ }^{83}$ M. Tsurtsumia, The Evolution..., p. 69-71.

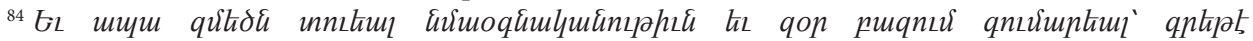

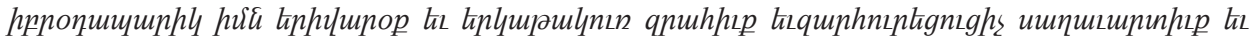

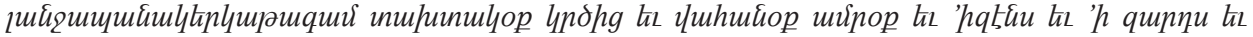

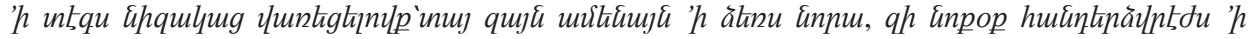

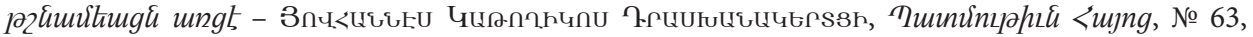

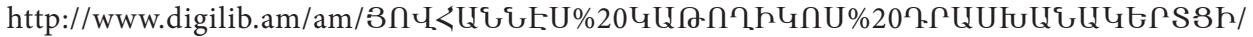
library/178 [15 III 2019].

${ }^{85}$ ОванЕС ДРАСХанаКеРТцИ, История АрменИи, trans. М. ДАРБИНЯн-МЕлИКян, Ереван 1986, p. 217.

${ }^{86}$ Yovhannēs Drasxanakertc'i's, History of Armenia, K. Maksoudian, Atlanta 1987.
} 
his movement (e.g. the Hovhannis Protospatharius presents the Gospel to the Virgin miniature in the Adrianople Gospel (1007) (pic. 19) ${ }^{87}$.

Additionally, visible on the riders' arms are some rings, possibly a mail armour, which consisted of small metal rings, linked together in a pattern, to form a mesh. In my opinion, the warriors wore a mail armour under the lamellar armour. A combination of the mail and lamellar armour can be found on Goliath's relief from Aghtamar Island (pic. 5) ${ }^{88}$.

As can be seen, the infantryman and the two horsemen on the right side of the relief are represented without any armour, only in tunics/garments. I believe that the majority of warriors (ordinary soldiers) and militia used popular and cheap leather armour which had less protective properties than metal.

Obviously, only noblemen (azats) had good armours (lamellar, scale or mail), but even these were not an ideal protection against arrows, because the latter could hit the little junctions between the plates. For example, when the Seljuk Turks first came to Armenia in 1016, they fought a battle against Vaspurakan king Senekerim Artsruni (1003-1021). Matthew of Edessa $\left(12^{\text {th }} \mathrm{c}\right.$.) described this battle in the following way ${ }^{89}$ : the foreigners [Seljuks] struck and wounded with their arrows many Armenian troops. Now when Shapuh [Armenian commander] saw this, he said to David [son of Senekerim]: "King, turn back from the enemy, because most of our troops have been wounded by arrows. Let us go and prepare [armoured] garments to resist the arrows which we see them fighting with"90.

${ }^{87}$ Gospel of Adrianopolis, Mekhitarists Library, Ms. 887, fol. 8.

${ }^{88}$ It needs to be noticed that Goliath's lamellar is presented schematically, because the row of lamellar plates and strips of leather (with holes) are presented separately while they should be overlapping. Probably the master would have liked to depict a banded lamellar but did it schematically. In a banded lamellar, the band is clearly visible because the edge of the leather covering the front of the upper plate forms the upper line of the band, and the piece of leather lining in the lower plate creates the lower line of the band. This leather band was placed between the rows, separating the plates and neutralizing the scissors effect caused by their movement, which may cut the thongs - M. Tsurtsumia, The Evolution..., p. 71-74; T. Dawson, Banded..., p. 16. However, R. D'Amato believes that the lamellae in this armour do not overlap but are fixed to the leather side by side. He thinks that the colour is now missing and it cannot be determined if the laces were represented on the surface. The lines are those of the leather band placed between the rows, separating the plates and neutralizing the scissors effect caused by their movement, which may cut the thongs. Goliath's lamellar armour does not have a narrow band of leather placed between the plates but a wide leather band fully lining the plates. Such armour is more flexible horizontally and is easy to make, and it is simplified further by riveting the plates on to the leather (instead of fixing them by means of thongs only). In fact, the four holes in each petal correspond to riveting holes. Idea courtesy of R. D’Amato.

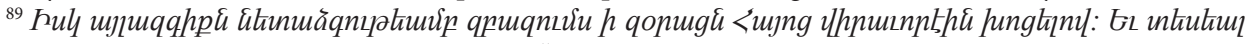

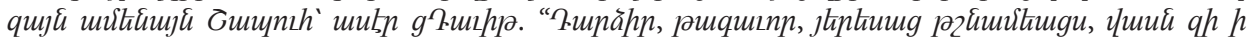

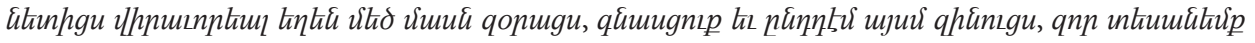

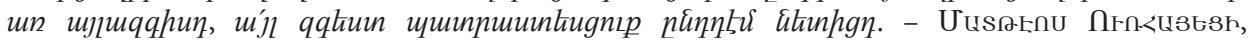

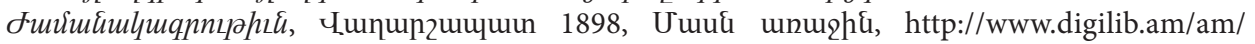

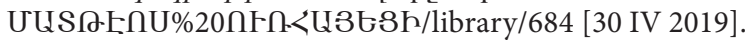

${ }^{90}$ Armenia and the Crusades, Ten to Twelfth Centuries. The Chronicle of Matthew of Edessa, 1.1, № 44-45, trans. A. Dostourian, Lanham 1993. For more information about Matthew of Edessa's 


\section{Stirrups}

Each equestrian is represented with stirrups (pic. 2:3), which significantly enhance the rider's stability, facilitating a more effective delivery of missiles (arrows or javelins) from the horseback, lance charges and close-quarter combat with swords, maces, axes, etc. ${ }^{91}$ Stirrups were known in the Eastern Roman Empire ${ }^{92}$ and Sassanid $\operatorname{Iran}^{93}$ from $6^{\text {th }}-7^{\text {th }} c$., and in Armenia as well ${ }^{94}$.

The stirrups visible on the relief have a triangular form with oval bows. Similar stirrups are presented in the Homilies of St. Gregory of Nazianzus (pic. 22, 33-34 ${ }^{95}$, in Georgian $\operatorname{art}^{96}$ and on St. Sargis's relief from The Cathedral of the Holy Cross, Aghtamar Island (pic. 23), which, however, are more rounded and more similar to the actual archaeological specimens of the $10^{\text {th }}-11^{\text {th }}$ century from Hungary (see below).

V. Yotov created a typology of Hungarian stirrups $\left(10^{\text {th }}-11^{\text {th }} \mathrm{c}\right.$.), which were also popular in the Roman Empire and, probably, in Armenia too ${ }^{97}$. Some of them look similar to the stirrups presented on the door of the Msho Arakelots church but, unfortunately, no definitive statements can be made because of the schematic representation of the stirrups on the relief and lack of photographic publications of stirrups found in the territory of Armenia.

\section{Middle part of the relief}

\section{Trumpet}

In the middle of the relief, there is an infantryman without any weapons and armours but with a military trumpet (pic. 3). It is the first depiction of the trumpet in Armenian art, representing an Eastern Roman tuba, which can be compared with the pictures from Madrid Skylitzes $\left(12^{\text {th }} \text { c.) (pic. } 24\right)^{98}$ and the Homilies of St. Gregory of Nazianzus (879-883) (pic. 25) ${ }^{99}$.

Moreover, the trumpet was often mentioned in Armenian written sources. For example, Tovma Artsruni $\left(10^{\text {th }}\right.$ c.), describing the battle between Abbasid army

\footnotetext{
chronicle, see T. Andrews, Matt'eos Urhayec'i and His Chronicle. History as Apocalypse in a Crossroads of Cultures, Leiden 2017. Similar information was also found in Sempad the Constable's Chronicle $\left(13^{\text {th }}\right.$ c. $)$ - СмБат СПараПет, Летописb, trans. А. ГАЛСтяна, Ереван 1974, p. 15.

${ }^{91}$ K. Farrokh, G. Karamian, K. Maksymiuk, A Synopsis..., p. 56.

92 V. Yotov, Byzantine Weaponry..., p. 157-160.

${ }^{93}$ K. Farrokh, G. Karamian, K. Maksymiuk, A Synopsis..., p. 57.

${ }^{94}$ D. Nicolle, Sassanian Armies..., p. 56-57, lett. G.

${ }^{95}$ Homilies of St. Gregory of Nazianzus, f. 409 v, 440 r.

${ }^{96} \mathrm{M}$. Tsurtsumia, The Evolution..., pic. 7, 11, 14.

${ }^{97}$ V. Yoтоv, Byzantine Weaponry..., p. 157-160, fig. 14.

${ }^{98}$ Madrid Skylitzes, National Library of Spain, Ms. Graecus Vitr. 26-2, fol. 108 v.

${ }^{99}$ Homilies of St. Gregory of Nazianzus, f. $424 \mathrm{v}$.
} 
under the command of general Bugha ${ }^{100}$ against Vaspurakan's troops ruled by ishkhan (king) Ashot Artsruni (approx. 852) ${ }^{101}$, wrote: Banners and pennants fluttered, trumpets sounded, lyrs rang, drums buzzed... Everybody shouted, preparing themselves for battle ${ }^{102}$. Just like flags or banners, it was one of the most necessary items in any contemporary army, which helped a general organize the troops and give different orders during the battle ${ }^{103}$.

\section{Right side of the relief}

\section{Round shield}

In the right corner of the relief, two cavalrymen without any armour, instead only dressed in (padded?) tunics (having the shape of a cavalry Iranian coat), are represented. The only defensive weapon which can be seen on this relief is a round shield with a floral ornament (pic. 4).

There are many depictions of round shields with different ornaments in Armenian art. Some of them symbolized the warrior's affiliation to some regiment or clan, or were just an ornament, as in the case of the miniatures from the Taron Gospel $\left(11^{\text {th }} \text { c.) (pic. } 26\right)^{104}$, the Vehapar Gospel $\left(10^{\text {th }}-11^{\text {th }} \text { c.) (pic. } 27\right)^{105}$, the Kars Gospel (1029-1064) (pic. 28) ${ }^{106}$ or Goliath's relief from Aghtamar Island ${ }^{107}$ (pic. 5). Also, on the miniature from the Tsgrut Gospel (974) (pic. 29) ${ }^{108}$, some rings are visible on one of the shields, which could mean that the shield was metal-coated.

On the basis of the depictions in figurative sources, it can be assumed that simple (plain) round shields were the most popular in Armenia. However, convex round shields were also widespread, but they were rarely represented on figurative sources because of the complex nature of painting volumetric figures. For

\footnotetext{
${ }^{100}$ Despite the fact that it is a description of the Abbasid army, the same armament could have existed in Armenia (also because the Armenian chronicler knows these armaments and armour).

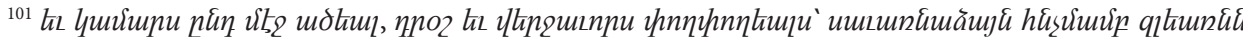

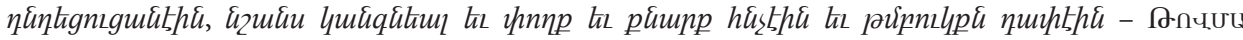

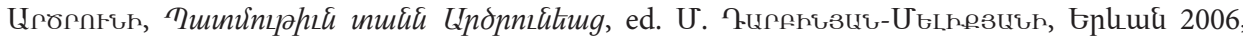
p. $148-149$.

102 Товма Арцруни и Аноним, История дома Арируни, еd. М. ДАрьинян-Меликян, Ереван 2001, p. 175-176. Similar description is presented on p. 298-299.

${ }^{103}$ For more information on the subject, see A. BüchlER, Horns and Trumpets in Byzantium: Images and Texts, HBSJ 12, 1, 2002, p. 23-59.

${ }^{104}$ Taron Gospel, Matenadaran Library, Ms. 6201, f. 8.

${ }^{105}$ Vehapar Gospel, Matenadaran Library, Ms. 10780, f. 71.

${ }^{106}$ Kars Gospel, Jerusalem Armenian Patriarchate, Ms. 2556, fol. 127. - S. Der Nersessian, L'Evangile..., p. 92-93, fig. 10.

${ }_{107}$ И. ОрьелИ, Избранные..., p. 96.

${ }^{108}$ Tsgrut Gospel (Tsgrut village, Armenia) (in situ), f. 9. - Н. КотАнджян, Цгрутское Евангелие, Ереван 2006, p. 81.
} 
instance, a miniature called The resurrection of Christ (12 $2^{\text {th }}$ c.) (pic. 20) ${ }^{109}$ from the Mekhitarists Library (Venice) features convex shields which are represented beside plain round shields. Moreover, on this miniature, a long kite-shaped shield is also depicted, which was generally regarded as a European development for cavalry. However, D. Nicolle thinks that kite-shaped shield may have appeared in the Middle East as an infantry shield even before it was adopted by equestrians in Western Europe and Kievan Rus'110.

Shields could be hanged by long or short leather straps attached to the back. The short strap was used to hold the shield, and the long one to hang it over the shoulder or neck when it was not in use. Perhaps the shield depicted on the relief did not have a handle, usually attached to the forearm, which allowed the rider to use both hands at the same time, providing sufficient protection to the left side of the torso, the region most exposed during melee combat ${ }^{111}$.

Shields were made from wood and sometimes covered with metal plates ${ }^{112}$ and could have an umbo (a metal boss nailed at the centre of the shield designed to deflect blows and as reinforcement of the shield). According to J. Haldon, in the $9^{\text {th }}-10^{\text {th }} \mathrm{c}$., the average diameter of the Byzantine large round shield for infantryman was $75 \mathrm{~cm}$, and for the horseman $-65 \mathrm{~cm}$, together with the umbo ${ }^{113}$.

One known mention of the umbo is made in the chronicle of Movses Kaghankatvatsi $\left(7^{\text {th }} / 10^{\text {th }}\right.$ c.). Describing the battle between Armenian lord Djuansher and his murderer called Varazo in $681 \mathrm{AD}$, the chronicler wrote: ...Djuansher took out his sword [unıukn] and attacked Varazo, but the weapon stuck in the golden umbo of the opponent's shield [ku quuhuud unulihuuann] and the lord could not pull out his sword [qunın£]...114

The remains of a wooden shield with an iron umbo and metal framework were found at the site of the Amberd castle (pic. 30) ${ }^{115}$. Unfortunately, the exact dating of these archaeological features cannot be determined $\left(9^{\text {th }}-13^{\text {th }} c\right.$. (?)), and due to a bad state of preservation, it is difficult to make any informed assumptions about them.

\footnotetext{
${ }^{109}$ Gospel № 141/102, fol. 77 r.

${ }^{110}$ A kite-shaped shield is also depicted on a Fatimid plate (10-11 c.), which was found in Armenia. - D. Nicolle, The Armies..., p. 19, 30.

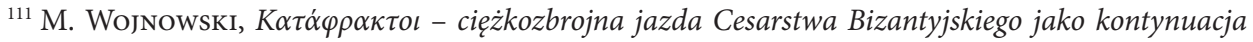
antycznych cataphracti i clibanarii, ZNUJ 132, 2005, p. 10, 19.

${ }^{112}$ К. Сорочан, Продовольство, сировина і реміснича продукція у Візантії IV-IX cm. професійна спеціалізація у виробництві та торгівлі. дис. на здобуття наук. ступеня канд. іст. наук, Харків 2015, р. 144.

${ }^{113}$ J. Haldon, Some Aspects..., p. 19, 33-34.

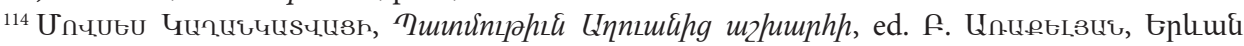
1983, p. 222-223; МовсеС КалАНкатуАцИ, История страны Алуанк, trans. Ш. Смбатяна, Ереван 1984, p. 117.

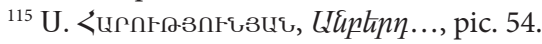




\section{Scabbard with chape}

Visible behind the shield is a part of a straight scabbard, which (pic. 4:4) was worn suspended from a sword belt or from the shoulder belt called baldric ${ }^{116}$. Most commonly, scabbards were made from metal, leather or wood covered with fabric ${ }^{117}$. At the end of this scabbard, there is a chape in the form of the letter $\mathrm{U}$ (pic. 4:5), which was popular in Byzantium ${ }^{118}$. V. Yotov thinks that this chape looks similar to the metal chapes $(10.5 \mathrm{~cm}$ long, $5.5 \mathrm{~cm}$ wide) unearthed in Bulgaria and dated to the second half of the $11^{\text {th }} \mathrm{c} .{ }^{119}$

Moreover, this form is also depicted on miniatures from the Taron Gospel (pic. 26) ${ }^{120}$, the Tsgrut Gospel (pic. 29) ${ }^{121}$ and the Menologion of Basil II (pic. 31) (22. $^{122}$ Thanks to this comparison, it can be theoretically assumed that such metal chapes were in use in the $11^{\text {th }}-12^{\text {th }} \mathrm{c}$. in Byzantium and Armenia (and perhaps across a larger area).

\section{Spear or sceptre}

The rightmost equestrian is holding a schematically represented stick with a sort of a head, which looks like a spear (pic. 4:6). However, Armenian historian Avetisian Kamsar thought that this horseman is an Armenian lord, an ishkhan (h2huwu), who is holding a sceptre (h2humumumu quuluquu - ishkhan's sceptre), which was a symbol of power ${ }^{123}$. The other cavalryman on the left side (St. George) holds only a long spear, with which he attacks the dragon. Although these weapons are presented too schematically, it is clear that the spear of the horseman is a long cavalry spear or a kontos (kontarion, pic. 6-7, 22-24, 33-34), popular in Armenia and Byzantium between the $7^{\text {th }}$ and the $12^{\text {th }}$ centuries $\mathrm{AD}^{124}$, which was about $2.7 \mathrm{~m}$ long for cavalrymen ${ }^{125}$ and $4.5 \mathrm{~m}$ for infantrymen ${ }^{126}$.

\footnotetext{
${ }^{116}$ S. Al-Sarraf, Close Combat..., p. 174; A. Hoffmeyer, Military ..., p. 92.

${ }^{117}$ P. Grotowski, Arms..., p. 345; T. Kolias, Byzantinische..., p. 148; I. Stephenson, Romano-Byzantine Infantry Equipment, London 2011, p. 96.

${ }^{118}$ Г. БАРАнов, Византийские..., р. 258.

${ }^{119} \mathrm{~V}$. Yotov is preparing an article about these chapes.

${ }^{120}$ Taron Gospel, Matenadaran Library, Ms. 6201, f. 7 v.

${ }^{121}$ Tsgrut Gospel (Tsgrut village, Armenia), f. 9. - Н. КОТАндЖян, Цгрутское..., p. 81.

122 This type of chape was presented on different miniatures in the Menologion of Basil II - 0070, 0094, 0097, 0104, 0121, 0131, 0136, 0139, 0144, 0172, 0181, 0187, 0188, 0195, 0206, 0211, 0216 etc. For more information, see Г. БАРАНОВ, Византийские..., p. 258.

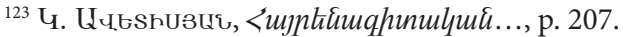

${ }^{124}$ Bibliography on the topic: T. Kolias, Byzantinische..., p. 185-213; P. Grotowski, Arms..., p. 323-327; J. Haldon, A Critical Commentary ..., p. 172, 186; T. Dawson, Fit for the Task..., p. 7-12;

R. D'Amato, The Varangian..., p. 39, etc.

125 T. Dawson, Byzantine Cavalryman..., p. 61.

${ }^{126}$ IDEM, Byzantine Infantryman..., p. 27.
} 
The kontarion was kept with one hand under an armpit, similarly to the knightly lance in Western Europe. This way of holding the lance was known in Byzantium from the $11^{\text {th }}-12^{\text {th }} \mathrm{c}$. It was one of the most effective methods because only one hand was used to hold a heavy kontarion and to perform a powerful lance charge while the other hand was used for manoeuvring the horse. Such an attack could only be carried out by keeping the cavalryman steady on his horse by means of stirrups and a raised saddlebow ${ }^{127}$.

\section{Helmets}

All the horsemen are represented in helmets or headgears. V. Abramian thinks that these helmets have a conical-hemispherical shape ${ }^{128}$ and, as can be seen, a mail, leather or scale aventail or coif was attached to them in order to protect the neck ${ }^{129}$. R. D'Amato wrote an excellent work on Byzantine helmets in the $9^{\text {th }}-12^{\text {th }}$ c., trying to create a detailed typology based on the technology of manufacturing, materials used and forms of helmets: conical, hemispherical, ridge, Phrygian-shaped, pointed, round off piece of banded construction, brimmed, mask-visor, and related headgears like the "skaplion" etc. ${ }^{130}$

Unfortunately, this typology cannot be used effectively in the present study because the helmets depicted on the reliefs are presented too schematically to allow reaching any substantial conclusions. However, based on Armenian figurative sources $\left(10^{\text {th }}-12^{\text {th }} \mathrm{c}\right.$.), it can be assumed that in Armenia there existed conical-hemispherical helmets (e.g. Goliath's relief from Aghtamar Island ${ }^{131}$, pic. 5) and conical-pointed helmets (Miniature from the Kars Gospel, pic. 28 ${ }^{132}$; Gospel 141 from Mekhitarists Library, pic. $20^{133}$; the Theodore Gospel, $12^{\text {th }}$ c., pic. 21$)^{134}$. Also, the chronicle of Matthew of Edessa $\left(13^{\text {th }} \mathrm{c}\right.$.) offers a description of the battle between Armenian lord Vasak and an Ethiop from Daylamites, where the author

\footnotetext{
${ }^{127}$ L. Peterson, The World of the Troubadours. Medieval Occitan Society, c. 1100-1300, Cambridge 1998, p. 39; В. Гуцул, Рицарська мілітарна технологія в Києво-Руській та Польсько-Литовській державах у XIII-XVI ст. інструменти, концепції та практики збройної боротьби. Автореферат дисертації на здобуття наукового ступеня кандидата історичних наук, Київ 2011, p. 13.

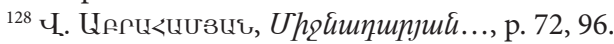

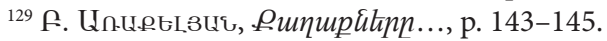

${ }^{130}$ R. D’Amato, Old..., p. 27-157.

${ }^{131}$ British historian D. Nicolle thought that Goliath was wearing a metal coif. - D. Nicolle, The Military..., p. 218-220. On the other hand, J. Davies believed that it is a pointed helmet. - J. Davies, Medieval..., p. 55.

${ }^{132}$ S. Der Nersessian, L'Evangile..., p. 92-93, fig. 10.

${ }^{133}$ Gospel № 141/102, fol. 77 r; S. Der Nersessian, Miniature..., p. 22-23, 26.

${ }^{134}$ Theodore Gospel, Jerusalem Armenian Patriarchate, Ms. 1796, fol. 88.
} 
mentioned a ridge helmet ${ }^{135}$ : Vasak with a steel sword struck the crest of his [opponent's] helmet and sliced that brave Qipchak [Ethiop] into two parts ${ }^{136}$. Theoretically, the helmet presented on the miniature from the Lviv Gospel (1198-1199) (pic. 32$)^{137}$ looks like a ridge (consisting of two parts), derived from the late Roman typology ${ }^{138}$. It is difficult to say anything more about the methods of producing helmets (i.e. whether one, two or more metal pieces were used) because no Armenian helmets from that time have been recovered.

\section{Conclusions}

Thanks to a comparative analysis, we proved that medieval figurative sources can be considered an accurate source for studying the medieval military history. Strong evidence for this is the presence of numerous specific military details on the relief studied. Also, this idea can be supported by referring to Armenian written sources (e.g. Stepanos Orbelian, $13^{\text {th }}$ c.). Describing Liparit Orbelian's armour from the battle against Seljuk Turks in 1049, the chronicler mentions almost all types of arms and armours which are presented on relief ${ }^{139}$ : Thus armed, he [Liparit] mounted his Arabian steed. He threw aside his shield with its gold designs and, taking a flexible javelin in his powerful left hand and a broad two-edged steel sword in his right hand, with his formidable axe/mace(?) like a blacksmith's mallet or a rock cutter's sledgehammer hanging at his side. [Liparit] bravely crossed the line of fighters, from one side to the other. His golden breastplate and helmet glittered like the sun ${ }^{140}$.

Thanks to military history, we can learn more about the scenes and motifs presented on miniatures, reliefs etc. and vice versa - figurative sources could show us different types of weapons, which can be compared with the ones mentioned or represented in the well-known Byzantine or Muslim sources. This is possible because, located between two civilizations (Byzantium and Muslim), Armenians adopted the best military solutions from both sides, creating their own culture.

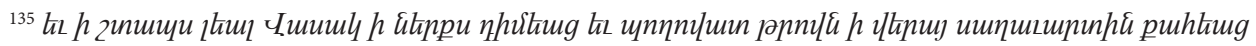

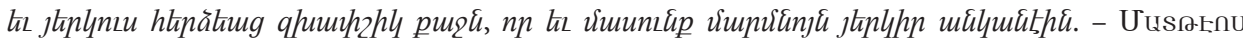

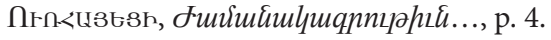

${ }^{136}$ Armenia and the Crusades..., 1.1, № 13-14.

${ }^{137}$ Lviv Gospel, National Library of Poland, Rps 8101 IIIS, 63 v.

${ }^{138}$ R. D’Amato, Old..., p. 86sqq.

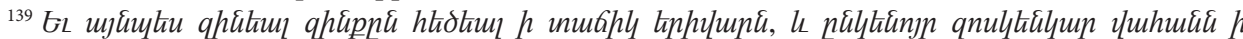

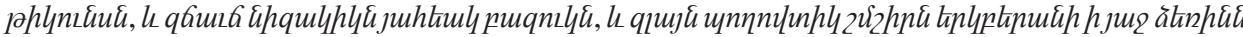

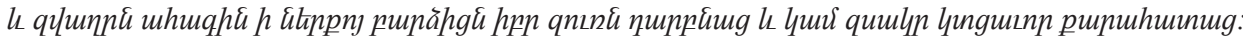

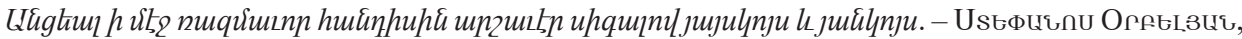

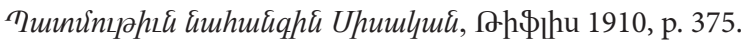

${ }^{140}$ Step'annos Orbelean, History of the State of Sisakan, trans. R. Bedrosian, Long Branch 2012, p. 195.
} 
I believe that this study offers further research perspectives in terms of a deeper archaeological and graphic analysis of the sources, which will allow a comprehensive reconstruction of the equipment of the Medieval Armenian soldier.

\section{Bibliography}

\section{Primary Sources}

Areg Gospel, Areg village (in situ) - D. Kouymjian, The Melitene Group of Armenian Miniature Painting in the Eleventh Century, [in:] R.G. Hovannisian, Armenian Kesaria/Kayseri and Cappadocia, Costa Mesa 2013, fig. 20.

Armenia and the Crusades, Ten to Twelfth Centuries. The Chronicle of Matthew of Edessa, trans. A. Dostourian, Lanham 1993.

Gospel № 141/102, Mekhitarists Library, fol. 77 r.

Gospel, Mekhitarian Library (Vienna), Ms. 697, f. 4 v, https://mycms-vs04.rrz.uni-hamburg.de/ sfb950/content/IAA/browseColl.xml [30 IV 2019].

Gospel of Adrianopolis, Mekhitarists Library, Ms. 887, fol. 8.

Homilies of St. Gregory of Nazianzus, National Library of France, gr. 510, f. 143, 409 v, 424 v, 440 r. Jerusalem Gospel, Jerusalem Armenian Patriarchate, Ms. 3624, f. 9.

Kars Gospel, Jerusalem Armenian Patriarchate, Ms. 2556, fol. 127. - S. Der Nersessian, L'Evangile du roi Gagik de Kars: Jérusalem No 2556, “Revue des études arméniennes” 18, 1984, p. 92-93, fig. 10 .

Lviv Gospel, National Library of Poland, Rps 8101 IIIS, 63 v.

Madrid Skylitzes, National Library of Spain, Ms. Graecus Vitr. 26-2, fol. 108 v.

MAttēos Owrrhayetsí, Zhamanakagrowtiwn, Vagharshapat 1898, http://www.digilib.am/am/ UUSßEПU\%20กFก-<U368h/library/684 [30 IV 2019].

Melitene Gospel, Matenadaran, Ms. 3784, f. 9.

Menologion of Basil II, Vatican Library, Ms. Vat. gr. 1613, f. 135. 0070, 0094, 0097, 0104, 0121, 0131, 0136, 0139, 0144, 0172, 0181, 0187, 0188, 0195, 0206, 0211, 0216.

Movses Kaghankatvatsi, Patmowtiwn Aghowanits'ashkharhi, ed. B. Arrak'elyan, Erewan 1983.

Movses KalankATUACI, Istorija strany Aluank, trans. Š. SMbATJANA, Erevan 1984.

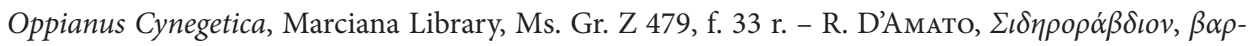

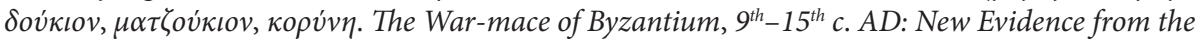
Balkans in the Collection of the World Museum of Man, Florida, "Acta Militaria Mediaevalia" 7 , 2011, fig. 17.

Ovanes Drashanakertci, Istorija Armenii, trans. M. Darbinjan-Melikjan, Erevan 1986.

Sleeve cross-guard. Unpublished archaeological find from Chernihiv, Ukraine (2018). Finding of grave robbers, https://vk.com/vtoroi_rim?w=wall-71532966_3071\%2Fall [30 IV 2019].

Smbat Sparapet, Letopis', trans. A. Galstjana, Erevan 1974.

SteP'Annos Orbelean, History of the State of Sisakan, trans. R. Bedrosian, Long Branch 2012.

SteP’anos Òrbelyan, Patmowtiwn nahangin Sisakan, Tìflis 1910.

Taron Gospel, Matenadaran Library, Ms. 6201, f. 8. 
Theodore Gospel, British Library, Ms. 19352, f. 352.

Theodore Gospel, Jerusalem Armenian Patriarchate, Ms. 1796, fol. 88.

Tovma Arcruni i Anonim, Istorija doma Arcruni, ed. M. Darbinjan-Melikjan, Erevan 2001.

Tovma Artsrowni, Patmowtiwn tann Artsrowneats', ed. M. Darbinyan-Melikyani, Erevan 2006. Tsgrut Gospel (Tsgrut village, Armenia), f. 9. - N. KotandŽJan, Cgrutskoe Evangelie, Erevan 2006.

Vehapar Gospel, Matenadaran Library, Ms. 10780, f. 71.

Vseobščaja istorija Asohika, trans. N. Èmina, Moskva 2011.

Yovhannēs Drasxanakertc'i's, History of Armenia, trans. K. Maksoudian, Atlanta 1987.

Yovhannēs Katoghikos Draskhanakerttsí, Patmowtiwn Hayots', http://www.digilib.am/am/

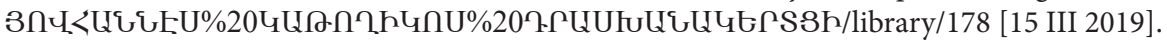

\section{Secondary Literature}

Abrahamyan V., Arhestnerë Hayastanowm IV-XVIII dd, Erewan 1956.

Abrahamyan V., Midzhnadaryan Hayastani zenkéri tesaknerë, "Thunuluu uuuuvuuluu pufiqupulu <UUก Q.U / Bulletin of State Historical Museum of Academy of Science ASSR” 2, 1949, p. 37-98.

Aleкsić M., Some Typological Features of Byzantine Spatha, “Зборник Радова Византолошког Института” / "Zbornik Radova Vizantološkog Instituta” 47, 2010, p. 121-138.

Al-Sarraf S., Close Combat Weapons in the Early Abbasid Period, [in:] A Companion to Medieval Arms and Armour, ed. D. Nicolle, Woodbridge 2002, p. 149-178.

Andrews T., Matt'eos Urhayec'i and His Chronicle. History as Apocalypse in a Crossroads of Cultures, Leiden 2017.

Arrakelyan B., Kảghaknerë ew arhestnerë Hayastanowm IX-XIII dd, Erewan 1958.

Atanasov G., Sv. Georgi Pobedonosec. Kult i obraz v Pravoslavnija Iztok prez srednovekovieto, Varna 2001.

Atanasov G., Vojnskite ikonografii, văorăženieto i snarjaženieto na sveti Georgi prez rannoto srednovekovie (V-X v.), [in:] Acta Musei Varnensis, I, Orăžie i snarjaženie prez kăsnata antičnost $i$ srednovekovieto $I V-X V$ v., ed. V. Jотоv, Varna 2002, p. 35-55.

Avetisyan A., Avetisyan K., Hayrenagitakan ètyowdner, Erewan 1979.

BARANov G., Bolgaro-vizantijskoe naveršie rukojati sabli s territorii Severo-Vostočnogo Pričernomor'ja, "Материалы по археологии и истории античного и средневекового Крыма" / "Materialy po archeologii i istorii antičnogo i srednevekovogo Kryma" 6, 2014, p. 84-93.

Baranov G., Nahodki rannesrednevekovyh sabel' "Bolgarskogo tipa» $v$ bassejne verhnego i srednego tečenija Dnestra, "Материалы по археологии и истории античного и средневекового Крыма" / "Materialy po archeologii i istorii antičnogo i srednevekovogo Kryma" 8, 2016, p. 76-92.

BARANOv G., Novaja nahodka perekrest'ja i naveršija rukojati vizantijskogo meča s territorii Čerkasskogo rajona Čerkasskoj oblasti Ukrainy, “Материалы по археологии и истории античного и средневекового Крыма" / "Materialy po archeologii i istorii antičnogo i srednevekovogo Kryma" 7, 2015, p. 87-105.

Baranov G., Perekrest'e meča iz raskopok vizantijskogo Chersona, "Военная археология" / "Voennaja archeologija" 4, 2018, p. 31-42.

Baranov G., Vizantijskie (sredizemnomorskie) meči s perekrest'jami s muftoj IX-XI vv., "Материалы по археологии и истории античного и средневекового Крыма" / "Materialy po archeologii $\mathrm{i}$ istorii antičnogo i srednevekovogo Kryma" 9, 2017, p. 248-283. 
Baranov G., Vizantijskij meč s territorii Ukrainy, [in:] Vojna i oružie. Novye issledovanija i materialy, pars 1, Sankt-Peterburg 2017, p. 171-177.

Bedrosian R., Armenia during the Seljuk and Mongol Periods, [in:] The Armenian People from Ancient to Modern Times, vol. I, ed. R. Hovannisian, New York 1997, p. 241-271.

BerežYns'kij V., Zbroja Kyïvs'koï Rusi. Bulava, Kyï 1998.

Büchler A., Horns and Trumpets in Byzantium: Images and Texts, "Historical Brass Society Journal" $12,1,2002$, p. 23-59.

Burton R., The Book of the Sword. A History of Daggers, Sabers, and Scimitars from Ancient Times to the Modern Day, New York 2014.

The Church of the Holy Cross of Att'amar, ed. Z. Pogossian, E. Vardanyan, Leiden 2019.

A Companion to Medieval Arms and Armour, ed. D. Nicolle, Woodbridge 2002.

D’Amato R., The Betrayal: Military Iconography and Archaeology in the Byzantine Paintings of XI-XV Centuries AD Representing the Arrest of Our Lord, [in:] Weapons Bring Peace? Warfare in Medieval and Early Modern Europe, ed. L. Marek, Wrocław 2010, p. 69-95.

D’Aмato R., Byzantine Imperial Guardsmen, 925-1025, Oxford 2012.

D’Amato R., The Eastern Romans 330-1461 AD, Hong Kong 2007.

D'Amato R., Old and New Evidence on the East-Roman Helmets from the 9 to the 12 Centuries, "Acta Militaria Mediaevalia" 11, 2015, p. 27-157.

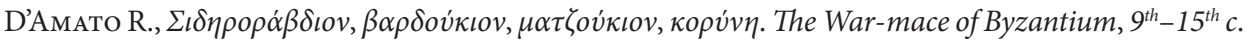
$A D$ : New Evidence from the Balkans in the Collection of the World Museum of Man, Florida, "Acta Militaria Mediaevalia" 7, 2011, p. 7-48.

D’Aмато R., The Varangian Guard 988-1453, Oxford 2010.

Dadoyan S., The Armenians in the Medieval Islamic World. Armenian Realpolitik in the Islamic World and Diverging Paradigms Case of Cilicia Eleventh to Fourteenth Centuries, vol. II, London 2013.

Davies J., Medieval Armenian Art and Architecture. Church of the Holy Cross, Aght'amar, London 1991.

Dawson T., Armour Never Wearies: Scale and Lamellar Armour in the West, from the Bronze Age to the $19^{\text {th }}$ Century, Cheltenham 2013.

Dawson T., Banded Lamellar - a Solution, "Varangian Voice" 23, 1992, p. 16.

Dawson T., Byzantine Cavalryman c. 900-1204, Oxford 2009.

DAwson T., Byzantine Infantryman. Eastern Roman Empire c. 900-1204, Oxford 2007.

Dawson T., Fit for the Task: Equipment Sizes and the Transmission of Military Lore, Sixth to Tenth centuries, "Byzantine and Modern Greek Studies" 32, 2007, p. 1-12.

Dawson T., Klivanion Revisited: an Evolutionary Typology and Catalogue of Middle Byzantine Lamellar, "Journal of Roman Military Equipment Studies" 12/13, 2001/2002, p. 89-95.

Dawson T., Kremasmata, Kabadion, Klibanion: Some Aspects of Middle Byzantine Military Equipment Reconsidered, "Byzantine and Modern Greek Studies" 22, 1998, p. 38-50.

Dawson T., The Myth of the "Varangian Rhomphaia": a Cautionary Tale, "Varangian Voice" 22, 1992, p. 24-26.

Dawson T., Suntagma Hoplon: The Equipment of Regular Byzantine Troops, c. 950 to c. 1204, [in:] A Companion to Medieval Arms and Armour, ed. D. Nicolle, Woodbridge 2002, p. 81-96.

Der Nersessian S., Aght'amar. Church of the Holy Cross, Cambridge 1965.

Der Nersessian S., Armenian Art, London 1978.

Der Nersessian S., The Date of the Initial Miniatures of the Etchmiadzin Gospel, "Études byzantines et arméniennes" 1, 1973, p. 535-538. 
Der Nersessian S., L'Evangile du roi Gagik de Kars: Jérusalem No 2556, "Revue des études arméniennes" 18, 1984, p. 85-107.

Der Nersessian S., An Introduction to Armenian Manuscript Illumination, Selections from the Walters Art Gallery, Baltimore 1974.

Der Nersessian S., Miniature Painting in the Armenian Kingdom of Cilicia from the Twelfth to the Fourteenth Century, vol. I, Washington 1993.

The Door of the Arakelots (Targmanchats) Monastery in Mush, https://historymuseum.am/en/exhibitions_type/the-door-of-the-arakelots-targmanchats-monastery-in-mush/ [30 IV 2019].

Esajan S., Oružie i voennoe delo drevnej Armenii (III-I tys. do n.è.), Erevan 1966.

Farrokn K., Karamian G., Maksymiuk K., A Synopsis of Sasanian Military Organization and Combat Units, Siedlce-Tehran 2018.

GHAFAdARYAn K., Dvin kảghakë ew nra peghowmnerë, Erewan 1952.

Ghafadaryan K., Sovetakan Hayastani arradzhin tangaranë, "Lpuptip huuupulquluuf qhunnıpjnıfitiph / Herald of the Social Sciences" 12, 1974, p. 37-47.

Grotowski P., Arms and Armour of the Warrior Saints. Tradition and Innovation in Byzantine Iconography (843-1261), Leiden 2010 [= The Medieval Mediterranean, 87].

Gucul V., Rycars'ka militarna tehnologija v Kyïvo-Rus'kij ta Pol's'ko-Lytovs'kij deržavah u XIII-XVI st. Instrumenty, koncepciï ta praktyki zbrojnoï borot'by. Avtoreferat disertaciï na zdobuttja naukovogo stupenja kandydata istoryčnih nauk, Kyïv 2011.

Haldon J., A Critical Commentary on The Taktika of Leo VI, Washington 2014.

HaLdon J., Some Aspects of Byzantine Military Technology from the $6^{\text {th }}$ to the $10^{\text {th }}$ centuries, "Byzantine and Modern Greek Studies" 1, 1975, p. 11-47.

Haldon J., Warfare, State and Society in the Byzantine World, 565-1204, London 1999.

Haldon J., Wojny Bizancjum. Strategia, taktyka, kampanie, trans. N. Radomski, Poznań 2019.

HarowtYownyan S., Anberd, Erewan 1978.

Hay Zhoghovrdi Patmowtyown, vol. III, ed. B. Arrakelyan, Erewan 1976.

Heath I., Armies of the Dark Ages, 600-1066 AD, Worthing 1980.

Heath I., Byzantine Armies 886-1118, Oxford 1979.

Hoffmeyer A., Military Equipment in the Byzantine Manuscript of Scylitzes in the Biblioteca Nacional in Madrid, "Gladius" 5, 1966, p. 1-160.

Izmajlova T., Armjanskaja miniatjura XI veka, Erevan 1979.

Izmailova T., L'Iconographie du cycle des fêtes d'un groupe de codex arméniens d'Asie Mineure, "Revue des études arméniennes" 4, 1967, p. 125-166.

Jones L., Between Islam and Byzantium, Aldershot 2007.

Jones L., The Visual Expression of Power and Piety in Medieval Armenia: The Palace and Palace Church at Aghtamar, [in:] Eastern Approaches to Byzantium, Aldershot 2001, p. 221-241.

Jotov V., Perekrest'e meča iz Chersonesa, “Античная древность и средние века” / “Antičnaja drevnost' i srednie veka" 39, 2009, p. 251-261.

Joтоv V., Rannie sabli (VIII-X vv.) na Nižnem Dunae, [in:] Kul'tury Evrazijskih stepej vtoroj poloviny I tysjačeletija n.è, Samara 2010, p. 217-225.

Jотоv V., Văorăženieto i snarjaženieto ot bălgarskoto srednovekovie (VII-XI vek), Varna 2004.

Kalantarjana A., Dvin. Gorod Dvin i jego raskopki (1981-1985), vol. IV, Erevan 2008.

K’alant'Aryan A., Dvini nyowtảkan mshakowytë IV-VIII darerowm, Erevan 1970. 
K'Alant'Aryan A., Kentronakan taghamasi peghowmnerë 1964-1970 tt', Erevan 1976.

K'Alant'Aryan A., Pashtpanakan sparrazinowtyownë midzhnadaryan hayastanowm, "〈uulquluu氏

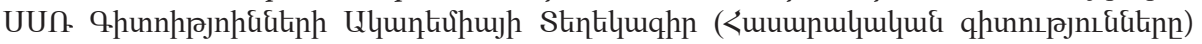
/ Bulletin of the Academy of Sciences of the Armenian SSR (Social Sciences)" 10, 1965, p. 68-74.

K'alantaryan A., Zenkérë V-VIII darerowm (Ëst Dvini hnagitakan peghowmneri), "Tuuuuuupuiquuhnuluuf hu氏ntiu / Historical-Philological Journal" 4, 1965, p. 241-248.

Kamburov S., “Arabski” rannosrednovekovni mečove v dnešnite bălgarski zemi”, “История” / "Istorija" 25, 3, 2017, p. 268-297.

KirpiČnikov A., Drevnerusskoe oružie, vol. II, Moskva-Leningrad 1966.

Kolias T., Byzantinische Waffen. Ein Beitrag zur byzantinischen Waffenkunde von den Anfängen bis zur lateinischen Eroberung, Wien 1988 [= Byzantina Vindobonensia, 17].

Kouymjian D., The Art of the Book: Armenian Medieval Illumination, [in:] Armenia. Imprints of a Civilization, ed. G. Uluhogian, B.L. Zekiyan, V. Karapetian, Milan 2011, p. 89-123.

Kouymian D., The Evolution of Armenian Gospel Illumination: The Formative Period $\left(9^{\text {th }}-11^{\text {th }}\right.$ Centuries), [in:] Armenian and the Bible. Papers Presented to the International Symposium Held at Heidelberg, July 16-19, 1990, ed. C. Burchard, Atlanta 1993, p. 125-142.

Kouymjian D., The Melitene Group of Armenian Miniature Painting in the Eleventh Century, [in:] R.G. Hovannisian, Armenian Kesaria/Kayseri and Cappadocia, Costa Mesa 2013, p. 79-115.

Kozak M., Bulava jak element ozbrojennja Galyc'kogo ta Volyns'kogo knjazivstv u XI-XIV stolittjah, [in:] Problemy istorii vijn i vijs'kovoho mystectva, ed. L.V. Vojtovyča, L’viv 2018, p. 51-79.

Maranci C., The Art of Armenia. An Introduction, Oxford 2018.

Matevosjan R., Padenie Bagratidskogo carstva po dannym armjanskih istorikov XI-XIII v., "Lpuptip huumpulquluuf qhunnıpjnı\&uliph / Herald of the Social Sciences" 10, 1988, p. 64-72.

Michalaк A., Wplywy wschodnie czy południowe? Z badań nad pochodzeniem buław średniowiecznych na ziemiach polskich, "Вісник Національного університету "Львівська політехніка" I "Visnyk Nacional'noho universytetu "L'vivs'ka politechnika" 571, 2006, p. 48-74.

Nicolle D., The Armies of Islam $7^{\text {th }}-11^{\text {th }}$ Centuries, Oxford 1982.

Nicolle D., Armies of the Caliphates (862-1098), Oxford 1998.

Nicolle D., Arms and Armour of the Crusading Era 1050-1350. Western Europe and the Crusader States, London 1999.

Nicolle D., Byzantine and Islamic Arms and Armour: Evidence for Mutual Influence, "GraecoArabica" 4, 1991, p. 299-325.

Nicolle D., Byzantine, Western European, Islamic and Central Asian Influence in the Field of Arms and Armour from the Seventh to Fourteenth Century AD, [in:] Islamic Crosspollinations. Interactions in the Medieval Middle East, Cambridge 2007, p. 94-118.

Nicolle D., The Cappella Palatina Ceiling and the Muslim Military Inheritance of Norman Sicily, "Gladius" 16, 1983, p. 45-145.

Nicolle D., Crusader Warfare. Muslims, Mongols and the Struggle against the Crusades, vol. II, London 2007.

Nicolle D., Manzikert 1071. Złamanie potegi Bizancjum, trans. M. BALICKI, Warszawa 2018.

Nicolle D., Saladin and the Saracens, Oxford 1986.

Nicolle D., Sassanian Armies. The Iranian Empire, Early $3^{\text {rd }}$ to mid- $7^{\text {th }}$ Centuries AD, Stockport 1996.

Nicolle D., The Military Technology of Classical Islam, vol. I-III [PhD Thesis, Edinburg 1982].

Nicolle D., Two Swords from the Foundation of Gibraltar, "Gladius" 22, 2002, p. 147-199. 
Norman I., A Likely Byzantine or Fatimid Sword of the $X^{\text {th }}-X I^{\text {th }}$ Centuries, 2019, http://iainnorman. com/essays/2019/01/a-likely-byzantine-or-fatimid-sword-of-the-xth-xith-centuries/ [30 IV 2019].

Orbeli I., Izbrannye trudy, vol. I, Moskva 1968.

OsKanYan K., Hayots' banakë Bagratownyats' shrdzhanowm (IX-XI darer) (chhraparakvats téknatsowakan atenakhosowtyown), Erewan 2010.

Patrik A., Msho Arrakélots'vanki dowrrë, [in:] Ėdzhmiatsin. Pashtònakan amsagir Hayrapetakan Atorroy S. Ëdzhmiatsni, vol. I, Ëdzhmiatsni 1952, p. 23-26.

Peterson L., The World of the Troubadours. Medieval Occitan Society, c. 1100-1300, Cambridge 1998.

Petrosyan H., Garrnin IX-XIV darerowm, Erewan 1988.

Popov S., The Maces from the Present Bulgarian Lands (10 $10^{\text {th }}-17^{\text {th }}$ c.), Sofia 2015.

Rabovyanov D., Early Medieval Sword Guards from Bulgaria, "Archaeologia Bulgarica" 2, 2011, p. 73-86.

Šaginjan A., Rasformirovanie arabskoj provincii Arminija vo vtoroj polovine IX veka, "Вестник Санкт-Петерсбурского Университета. История" / "Vestnik Sankt-Petersburskogo Universiteta. Istorija” 2, 2009, p. 213-223.

SoRočAn K., Prodovol'stvo, syrovyna i remisnyča produkcija u VizantiïIV-IX st. Profesijna specializacija u vyrobnyctvi ta torhivli. Dis. na zdobuttja nauk. stupenja kand. ist. nauk, Charkiv 2015.

Stepanjan N., Iskusstvo Armenii, Moskva 1989.

Stepanjan N., ČaKmaKČJan A., Dekorativnoe iskusstvo srednevekovoj Armenii, Leningrad 1971.

Stephenson I., Romano-Byzantine Infantry Equipment, London 2011.

Tatoyan R., Mush - Churches and Monasteries, https://www.houshamadyan.org/mapottomanempire/vilayet-of-bitlispaghesh/kaza-of-moush/religion/churches.html [30 VIII 2019].

Tнеотокіs G., Military Technology: Production and Use of Weapons, [in:] A Companion to the Byzantine Culture of War, ca. 300-1204, ed. Y. Stouraitis, Boston 2018, p. 440-473.

Toumanoff C., Caucasia and Byzantium, "Traditio" 27, 1971, p. 111-158.

Tsurtsumia M., The Evolution of Splint Armour in Georgia and Byzantium: Lamellar and Scale Armour in the $10^{\text {th }}-12^{\text {th }}$ Centuries, "Symmeikta" 21, 2011, p. 65-99.

Tsurtsumia M., The Mace in Medieval Georgia, "Acta Militaria Mediaevalia" 14, 2018, p. 87-114.

Tsurtsumia M., Medieval Sword and Sabre from the Georgian National Museum, "Acta Militaria Mediaevalia" 11, 2015, p. 159-172.

Walter C., The Origins of the Cult of Saint George, "Revue des études byzantines" 53, 1995, p. 295-326.

Walter C., The Warrior Saints in Byzantine Art and Tradition, Aldershot 2003.

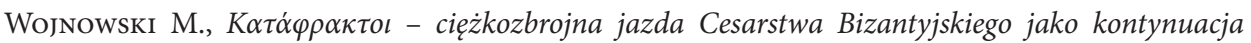
antycznych cataphracti i clibanarii, "Zeszyty Naukowe Uniwersytetu Jagiellońskiego" 132, 2005, p. $7-22$.

Yотоv V., Byzantine Time Swords (10-11 c.), "Studia Universitatis Cibiniensis” 1, 2011. p. 35-45.

Yoто V., Byzantine Weaponry and Military Equipment in the Homilies of St Gregory of Nazianzus (Paris, Gr. 510), "Fasciculi Archeologiae Historicae" 30, 2017, p. 153-163.

Yотоv V., The Kunagota Sword Guard and the Dating of Two Bronze Matrices for Hilt Manufacturing, [in:] Die Archäologie der frühen Ungarn, Mainz 2012, p. 219-226.

Yotov V., A New Byzantine Type of Swords ( $7^{\text {th }}-11^{\text {th }}$ Centuries), [in:] Niš and Byzantium, vol. IX, Niš 2011, p. 113-124. 


\begin{abstract}
Byzantium's arms and armours were researched by many historians. For that reason, the military history of the medieval Roman Empire enjoyed a dominant position in medieval historiography, with the consequence that very often the military history of small nations (under Roman influences) was written from the perspective of the Eastern Romans historians.
\end{abstract}

The aim of the paper is to change this perspective and give the subject of the medieval Armenian military the attention it deserves. The idea is to perform an analysis of the relief on the Door of the Msho Arakelots monastery, where four equestrians and one infantryman are depicted, and to compare it with other Armenian, Byzantine and Muslim sources.

In this relief, a spherical mace head and a sword with sleeve cross-guard are represented, suggesting many parallels with East-Roman archaeological and figurative sources. No less important is the depiction of the military trumpet because it is the first image of this object in Armenian art, which can be compared with pictures from the Madrid Skylitzes ( $13^{\text {th }} \mathrm{c}$.). In addition, the only defensive weapon which is presented in this relief is a round shield with a floral ornament. There are many depictions of round shields in Armenian miniatures and reliefs from $10^{\text {th }}-11^{\text {th }} \mathrm{c}$. Moreover, this relief is one of the few where stirrups and the chape of a scabbard are shown. These elements represent an important piece of information because these pictures can be compared with actual archaeological East-Roman artefacts to reconstruct their real look.

The conclusions are that the majority of Armenian weapons bear similarities to Byzantine ones but no less important are the Muslim influences, which have been found in some cases. Located between two civilizations (Byzantium and the Muslim Potentates), Armenians adopted the best solutions of their military technologies, creating their own culture. Moreover, thanks to this comparative analysis, further support will be given to the idea that medieval figurative sources are more or less accurate material for studying medieval military history.

Keywords: Armenia, Bagratids, Msho Arakelots, relief, military history, sleeve cross-guard, Byzantine Empire, Muslim world, weapon, armour.

\title{
Dmytro Dymydyuk
}

Ivan Franko National University of Lviv (Ukraine) Faculty of History

Department of History of Middle Ages and Byzantine Studies

Universytetska 1 str.

79000, Lviv, Ukraine dymydyuk_da@ukr.net 


\section{ILLUSTRATIONS}
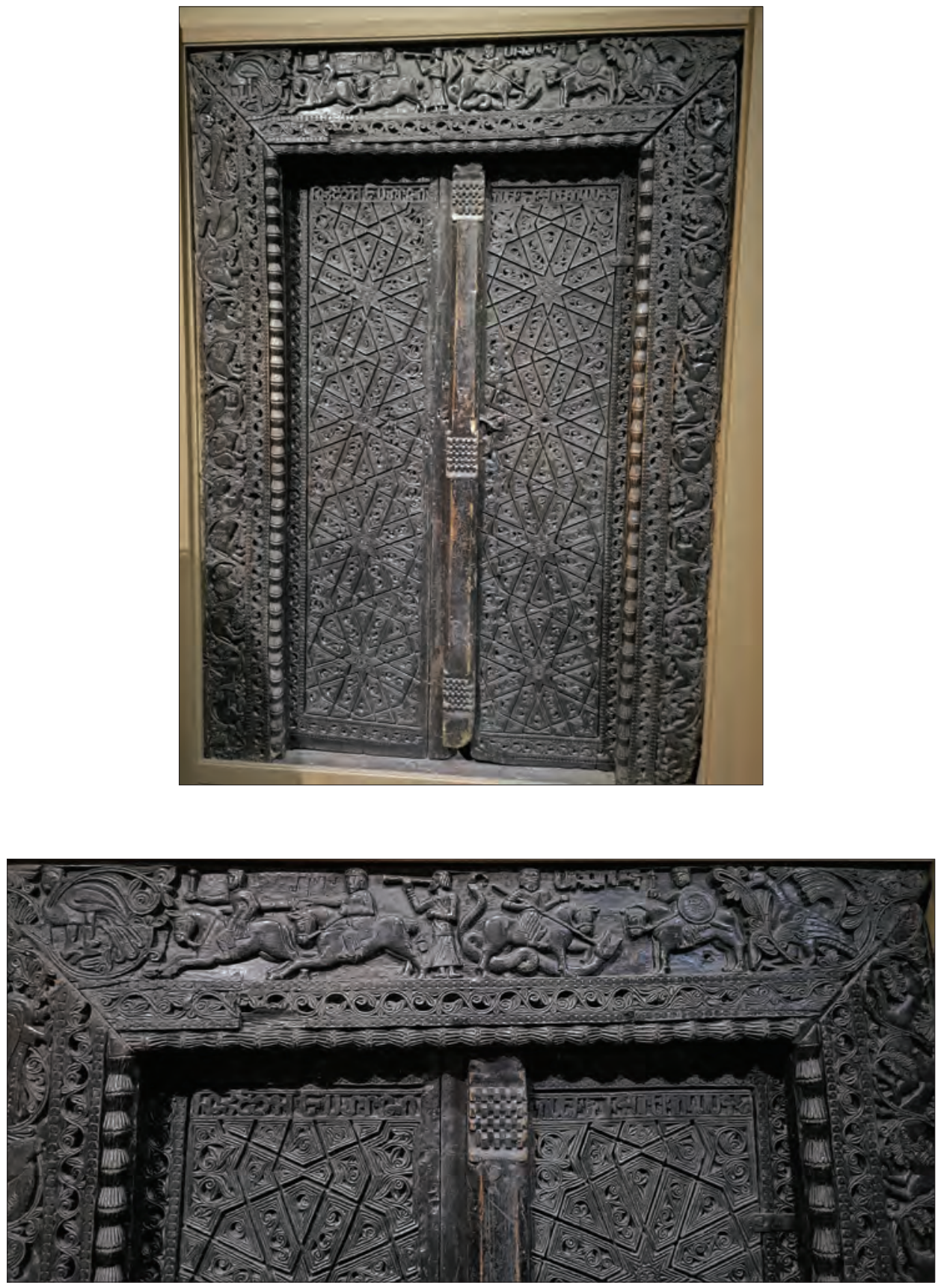

Fig. 1. Relief on the door of Msho Arakelots monastery (1134). Author's photo [30 IX 2019]. 

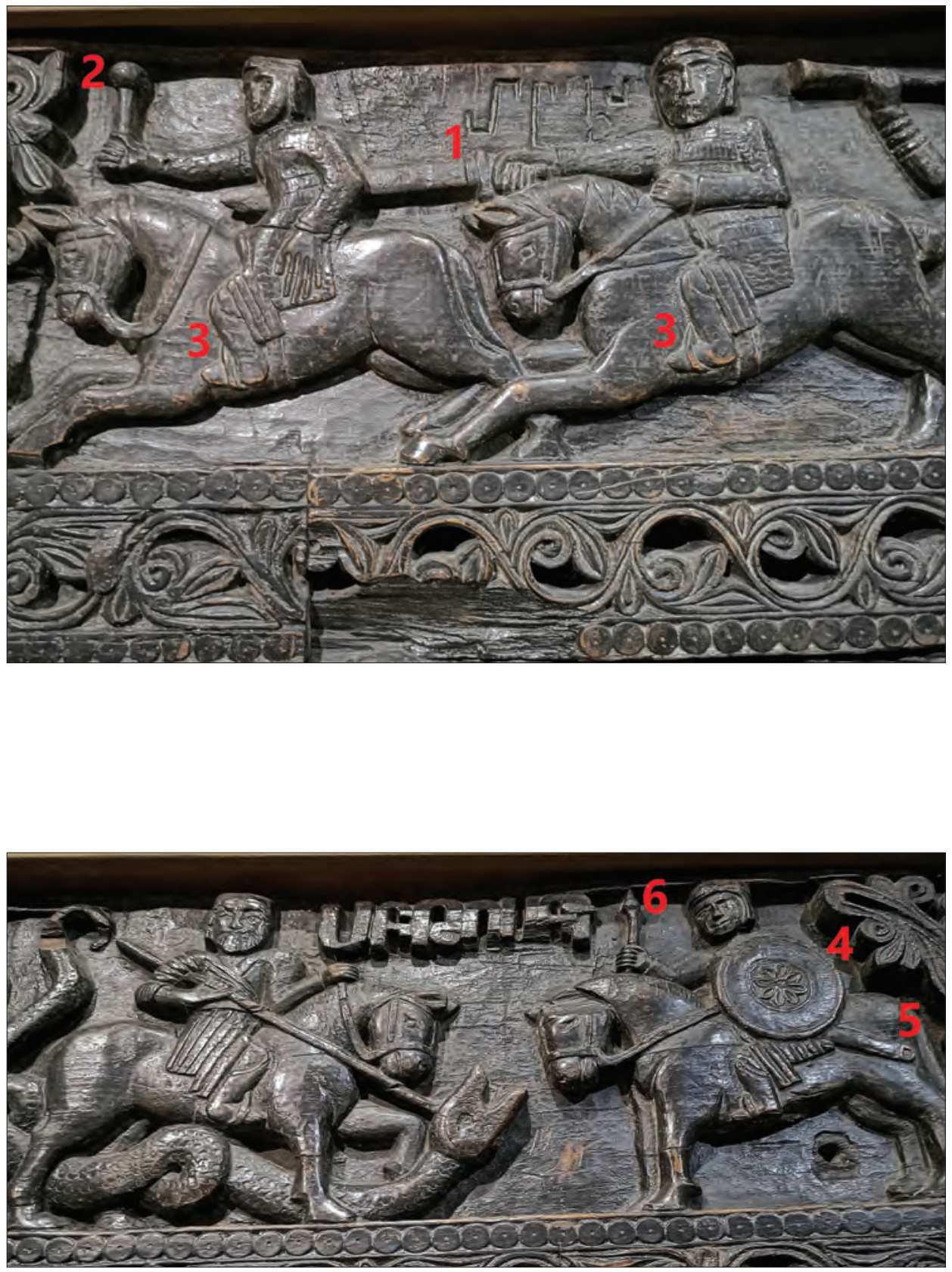

Fig. 2-3. Relief on the door of Msho Arakelots monastery (1134). Author's photo [30 IX 2019]. 


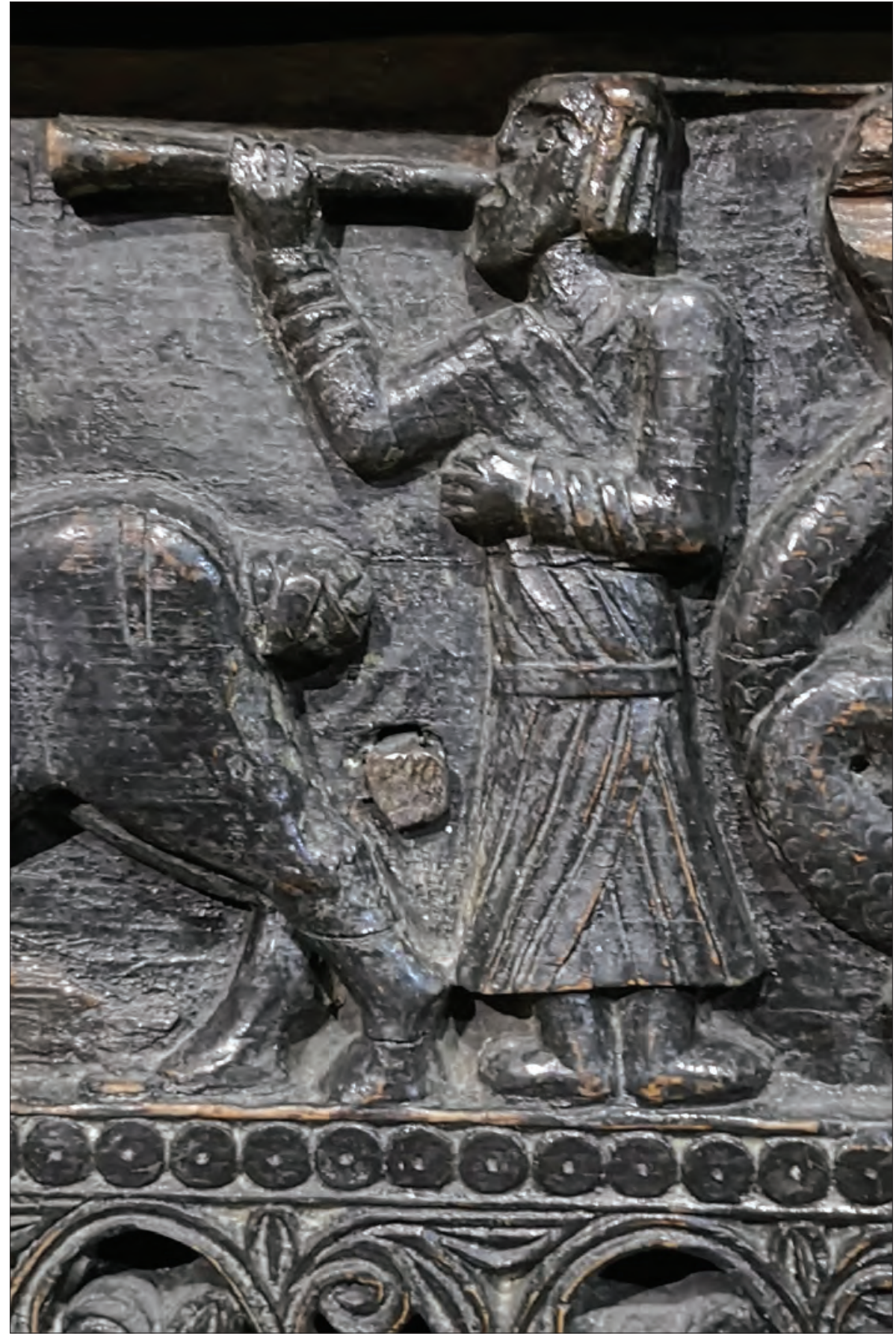

Fig. 4. Relief on the door of Msho Arakelots monastery (1134). Author's photo [30 IX 2019]. 


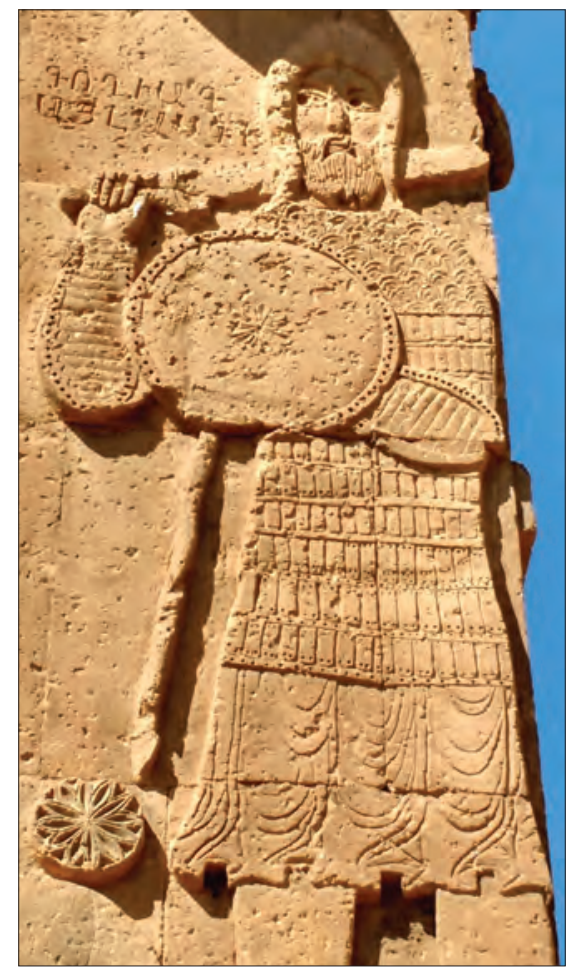

Fig. 5. Goliath's relief from The Cathedral of the Holy Cross, Aghtamar island (915-921, modern Turkey) (in situ). Author's photo [20 VIII 2019].

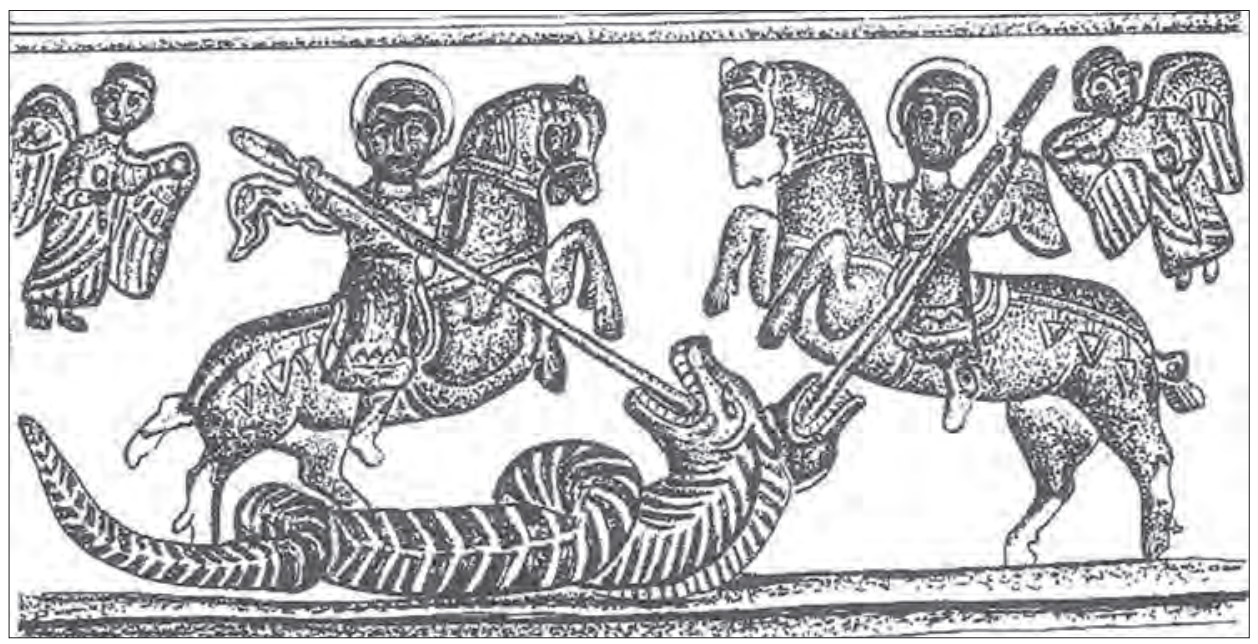

Fig. 6. Relief "St. George and St. Theodore slaying dragons" from the Church in Martvili, $7^{\text {th }}-8^{\text {th }}$ c. (Georgia). - Г. АтАнасов, Св. Георги Победоносеи. Култ и образ в Православния Изток през средновековието, Варна 2001, ріс. 244. 


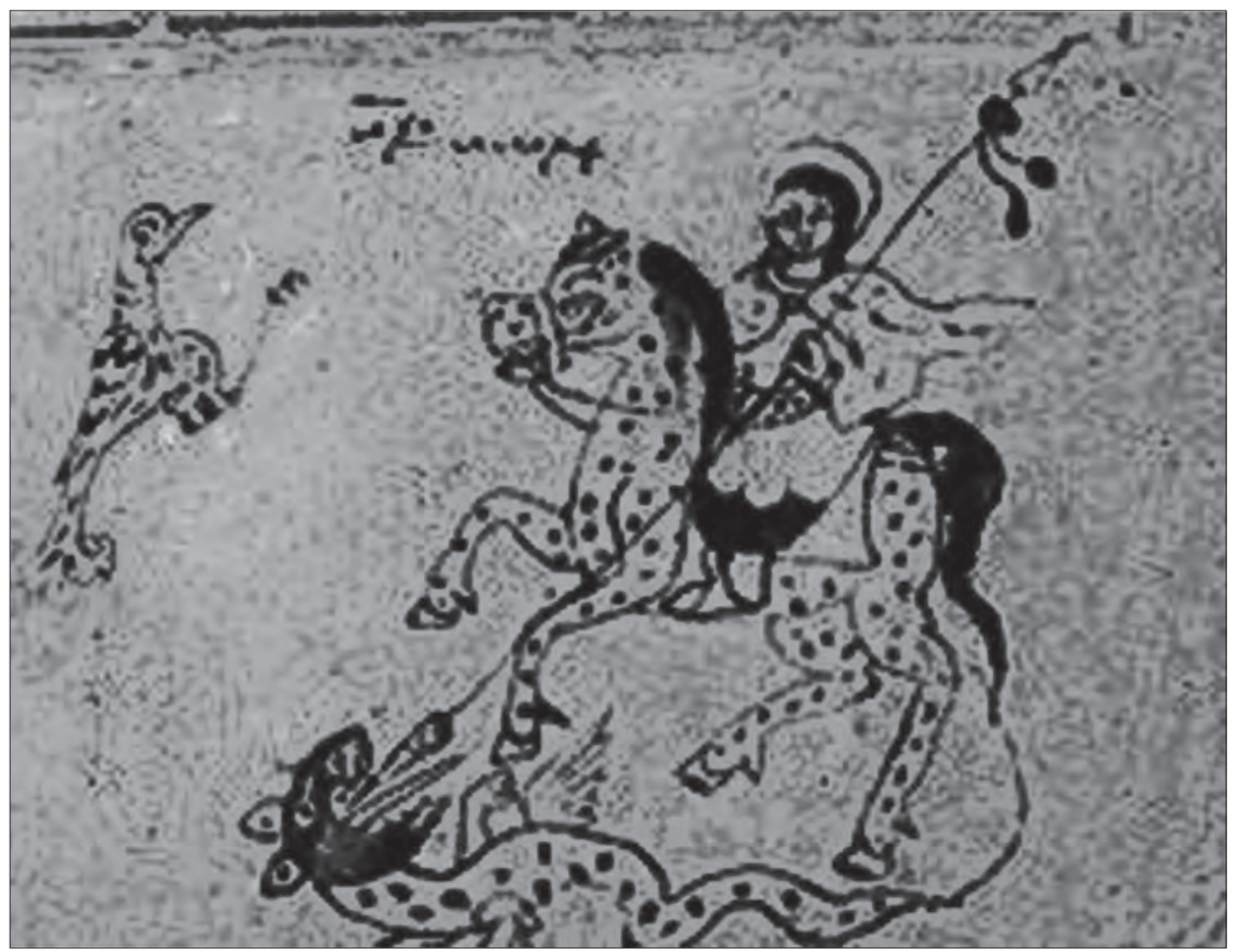

Fig. 7. Fragment of the miniature "St. Sargius" $\left(10^{\text {th }}\right.$ c. $)$ - Gospel, Mekhitarian Library (Vienna), Ms. 697, f. 4v, https://mycms-vs04.rrz.uni-hamburg.de/sfb950/content/IAA/ browseColl.xml [30 IV 2019].

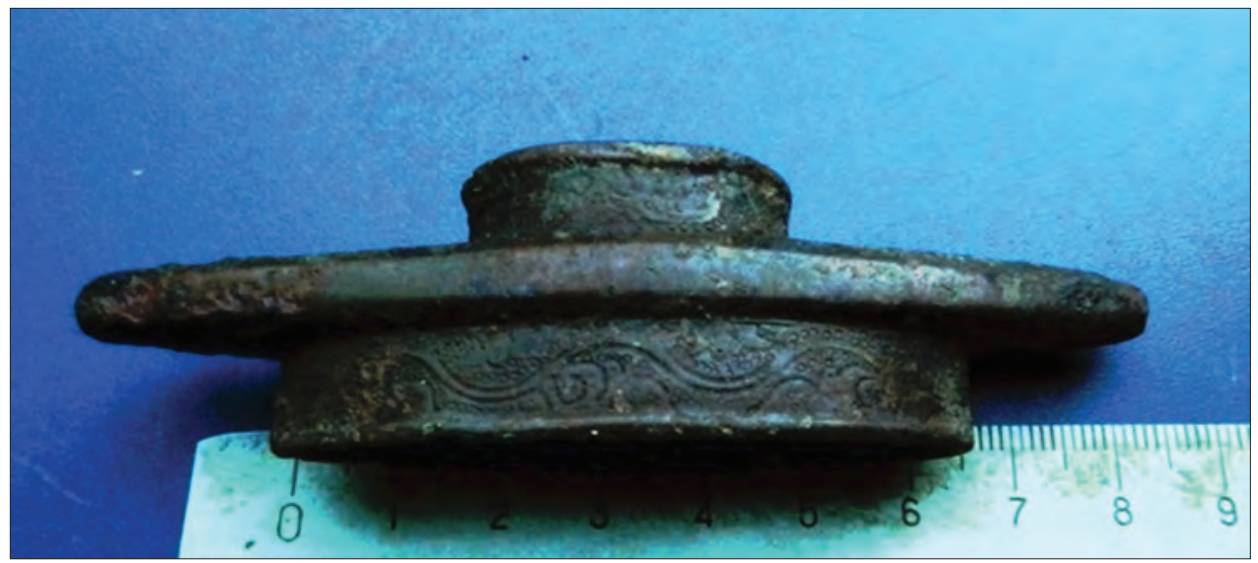

Fig. 8. Sleeve cross-guard. Unpublished archaeological find from Chernihiv, Ukraine (2018). Finding of grave robbers, https://vk.com/vtoroi_rim?w=wall-71532966_3071\%2Fall [30 IV 2019]. 

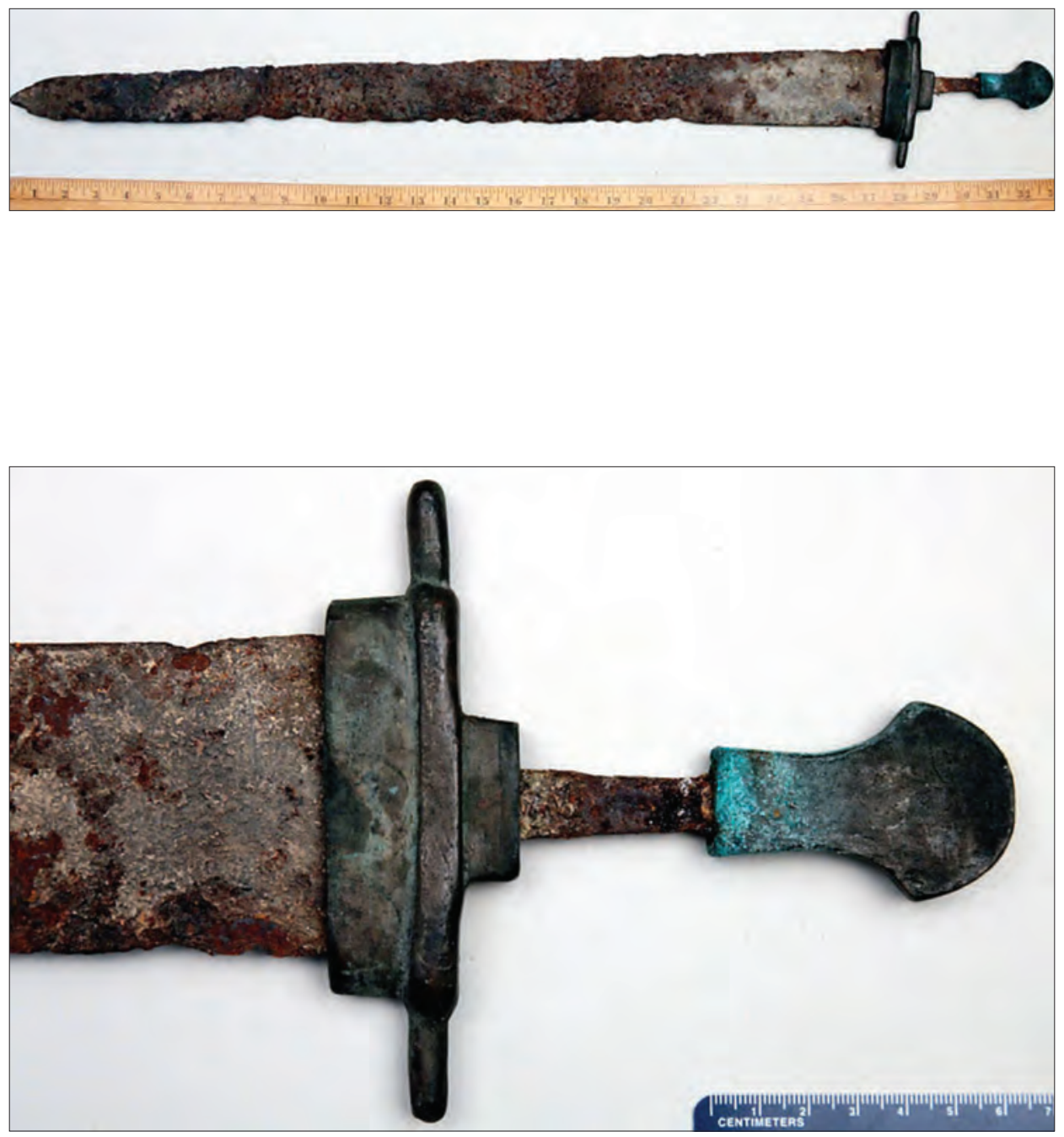

Fig. 9-10. Sleeve cross-guard. Unpublished archaeological find (private collection of Dr. Lee Jones). Territory of origin is unknown. - I. Norman, A Likely Byzantine or Fatimid Sword of the $X^{\text {th }}-X I^{\text {th }}$ Centuries, 2019, http://iainnorman.com/essays/2019/01/ a-likely-byzantine-or-fatimid-sword-of-the-xth-xith-centuries/ [30 IV 2019]. 


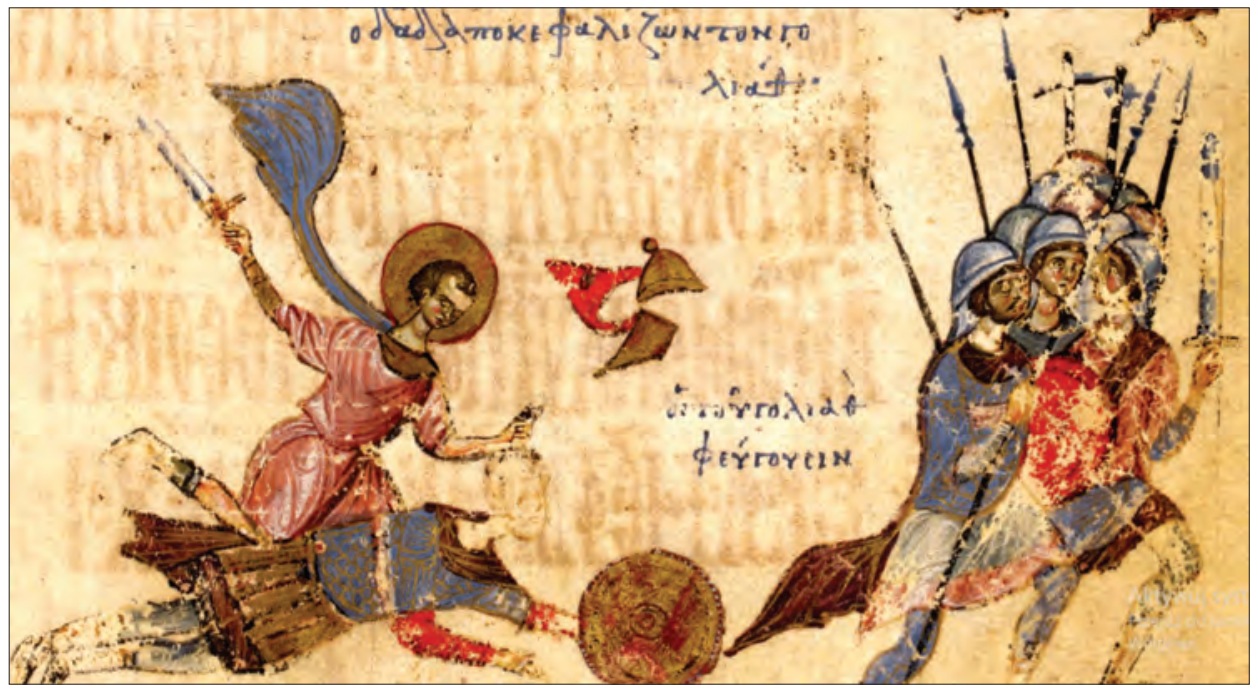

Fig. 11. Miniature "David defeats Goliath" (1066). - Theodore Gospel, British library, Ms. 19352,f. 191, http://www.bl.uk/manuscripts/Viewer.aspx?ref=add_ms_19352_f207v [30 IV 2019].

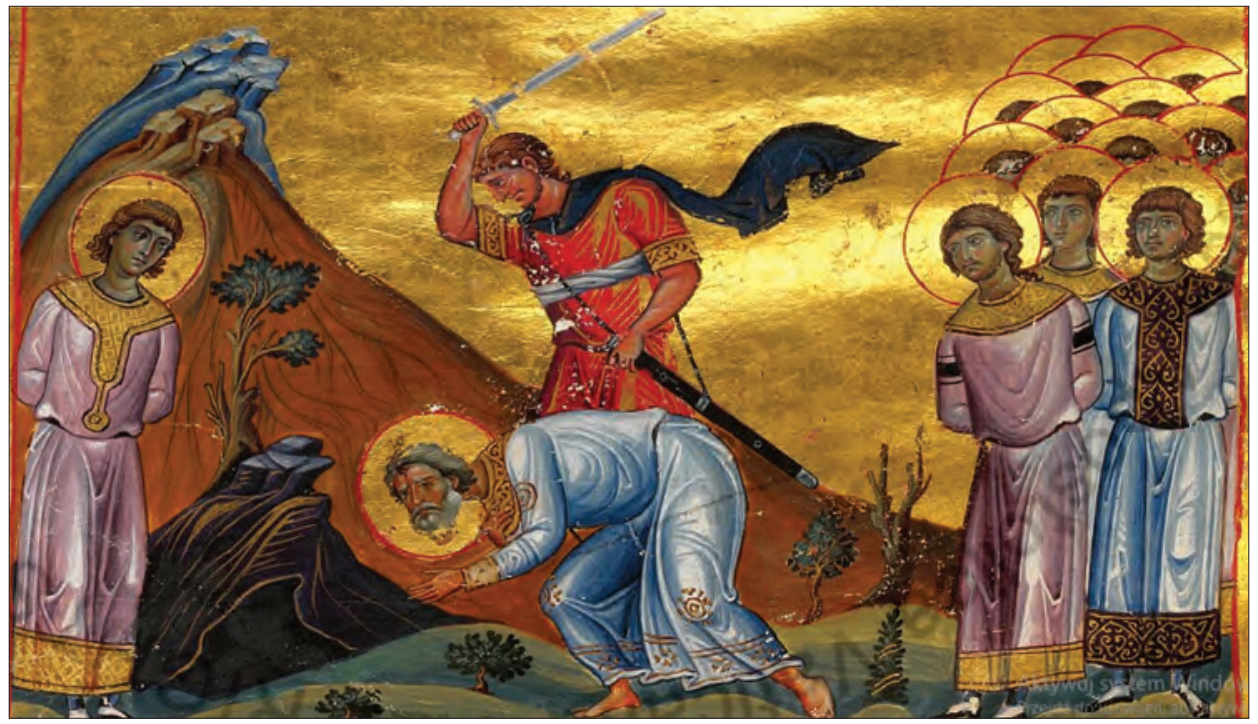

Fig. 12. Miniature "The Martyrdom of St. Arethas" (end of $10^{\text {th }} \mathrm{c}$.) where sword with sleeve cross-guard is depicted. - Menologion of Basil II, Vatican library, Ms. Vat. gr. 1613, f. 135, https://digi.vatlib.it/view/MSS_Vat.gr.1613 [30 IV 2019]. 


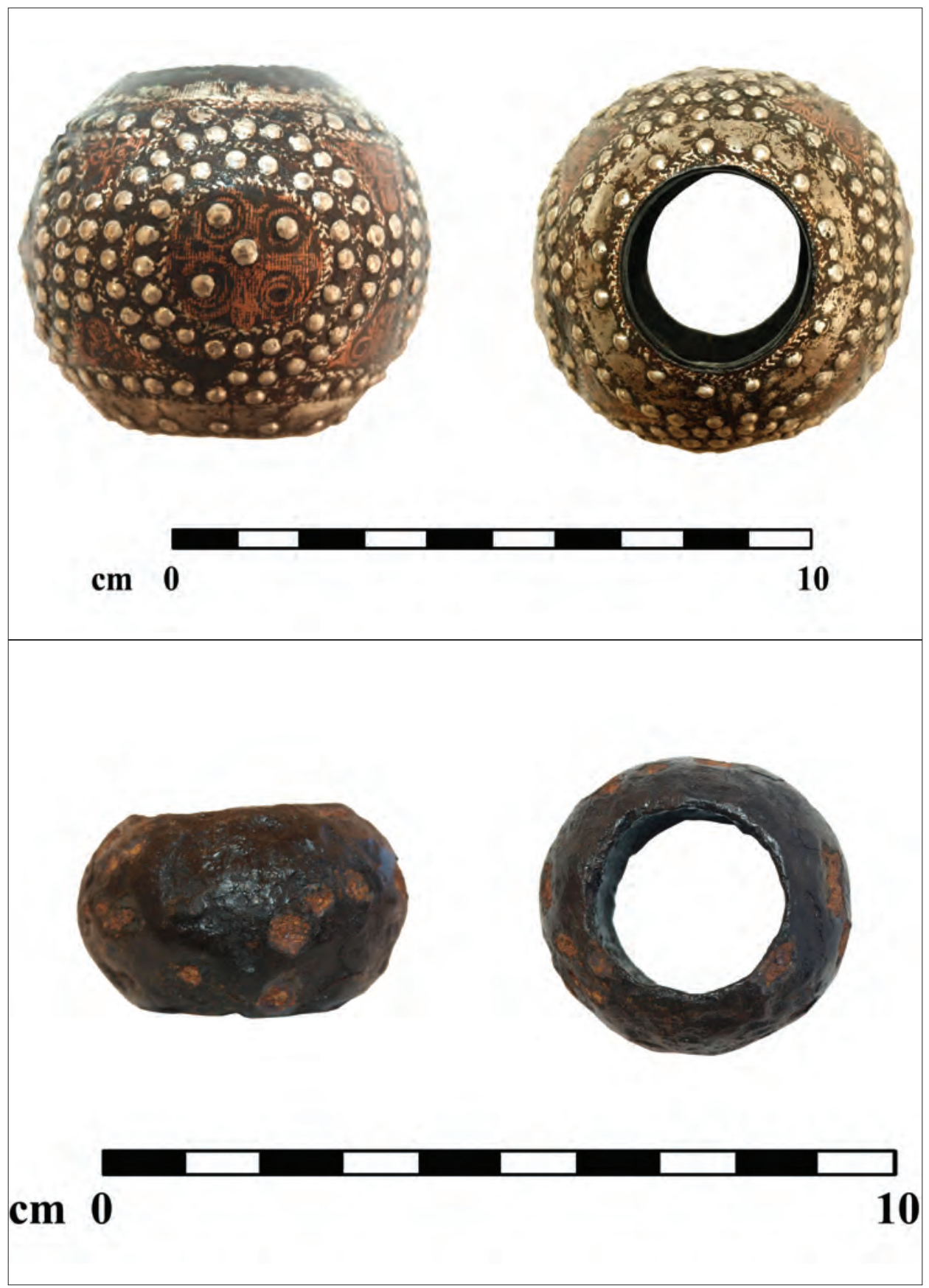

Fig. 14. (A and B) Iron, spherical mace heads $\left(11^{\text {th }}-12^{\text {th }}\right.$ c.). Vatevi Collection, Bulgaria. - S. Popov, The maces from the present Bulgarian lands $\left(10^{\text {th }}-17^{\text {th }} c\right.$.), Sofia 2015 , p. 130-131. Photo courtesy of S. Popov. 


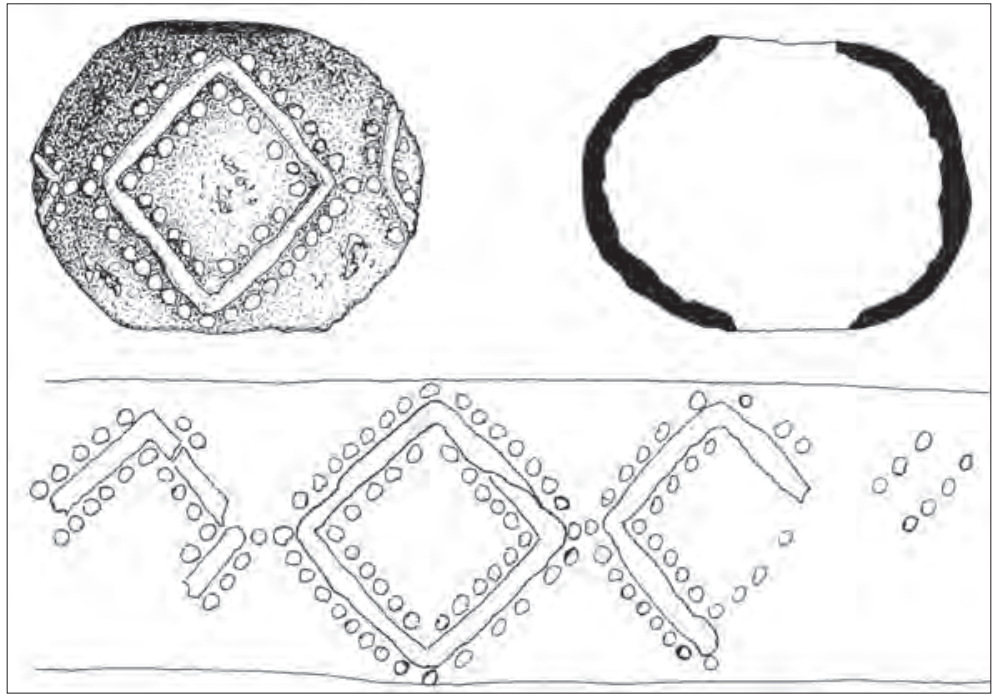

Fig. 13. Spherical mace from Panaguriste with silver decoration $\left(10^{\text {th }}-11^{\text {th }} \mathrm{c}\right.$. $)$. - В. Йотов, Въорбжението и снаряжението от българското средновековие (VII-XI век), Варна 2004, cat. 644.

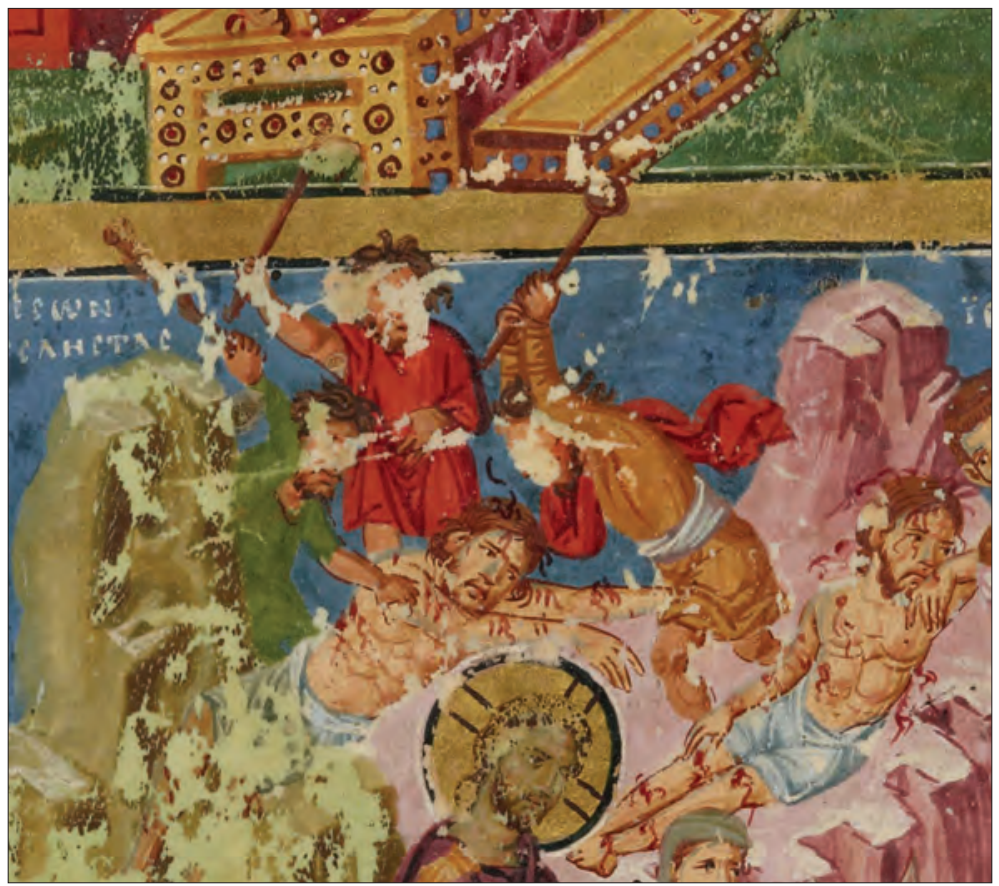

Fig. 15. Miniature "Good Samaritan stripped and beaten by three robbers" (Middle part), (879-883). - Homilies of St. Gregory of Nazianzus, National library of France, gr. 510, f. 300 (143), https://gallica.bnf.fr/ark:/12148/btv1b84522082/f542.planchecontact [12 IX 2019]. 


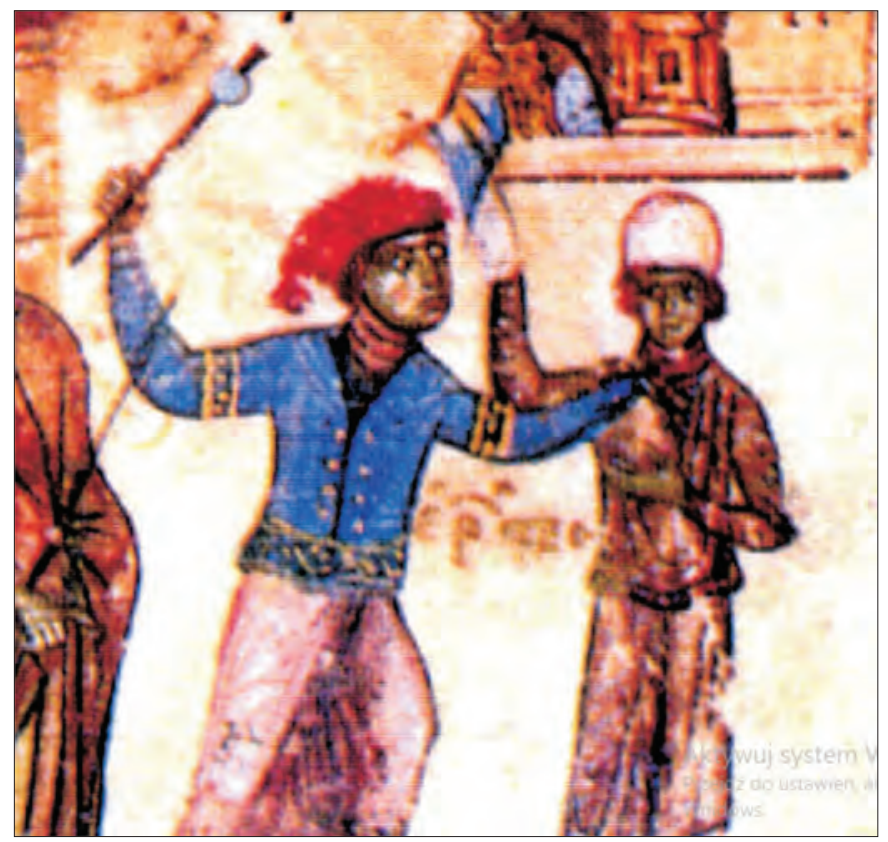

Fig. 16. Miniature "The power of Eros" $\left(10^{\text {th }} \mathrm{c}\right.$.) - Oppianus Cynegetica, Marciana Library,

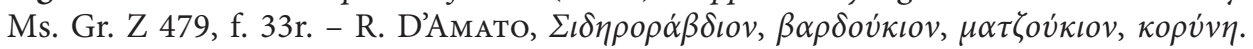
The war-mace of Byzantium, $9^{\text {th }}-15^{\text {th }} \mathrm{C}$. AD, AMM VII, 2011, fig. 17.

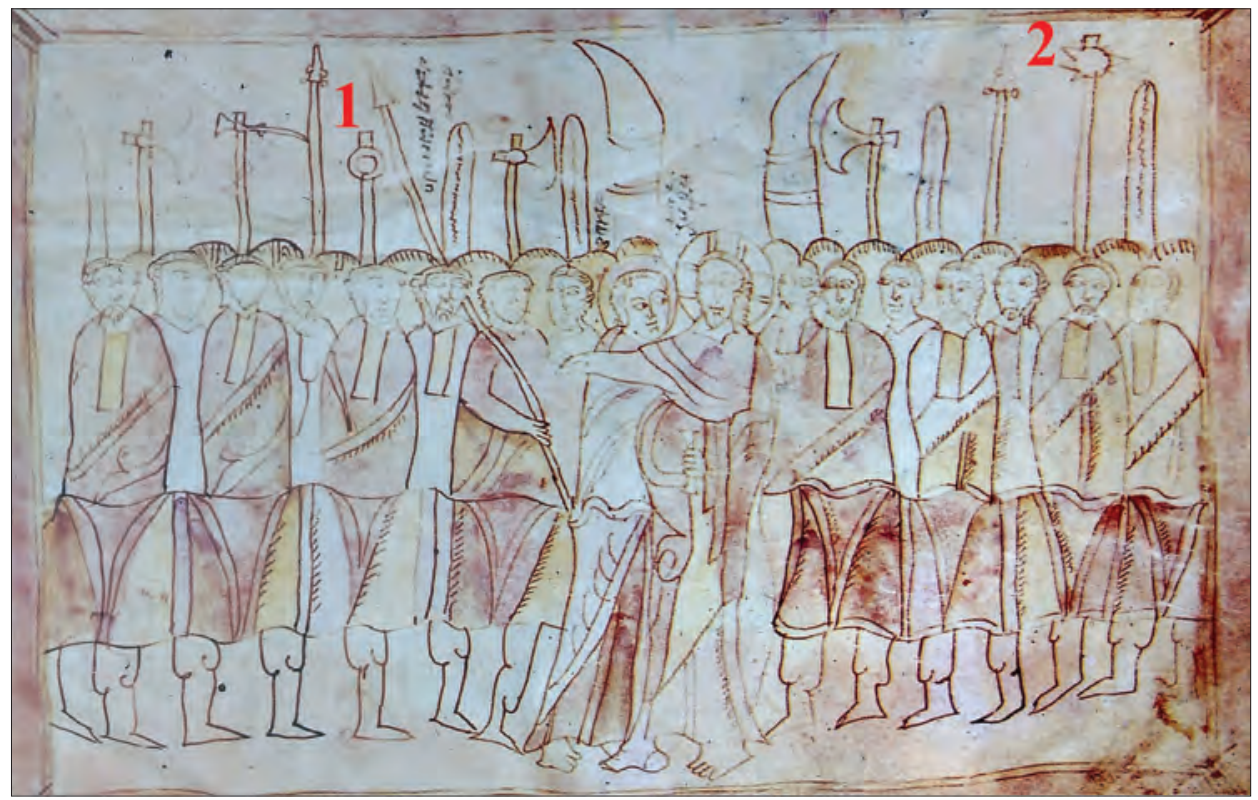

Fig. 17. Miniature "Judas Kiss" (1057). Author's photo [30 IX 2019]. 


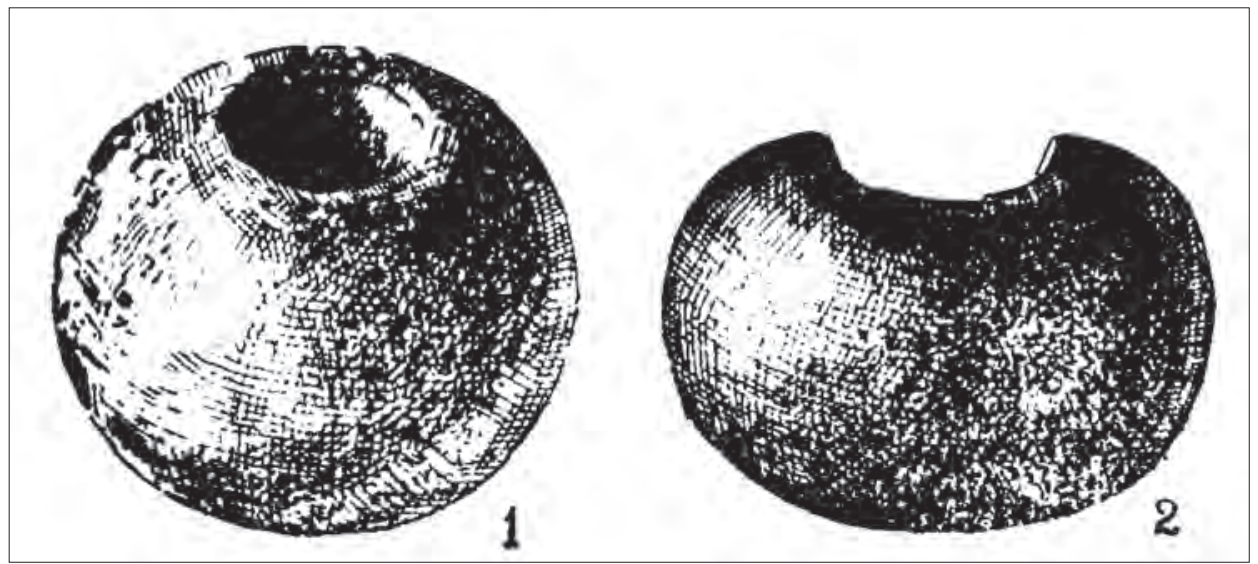

Fig. 18. I. The mace from former Echmiadzin museum (History museum of Armenia); II. The mace from Shengavit (History museum of Armenia) (3-1 millennium BC). - С. ЕСАян, Оружие и военное дело древней Армении (III-I тыс. до н. э.), Ереван 1966, p. 56.

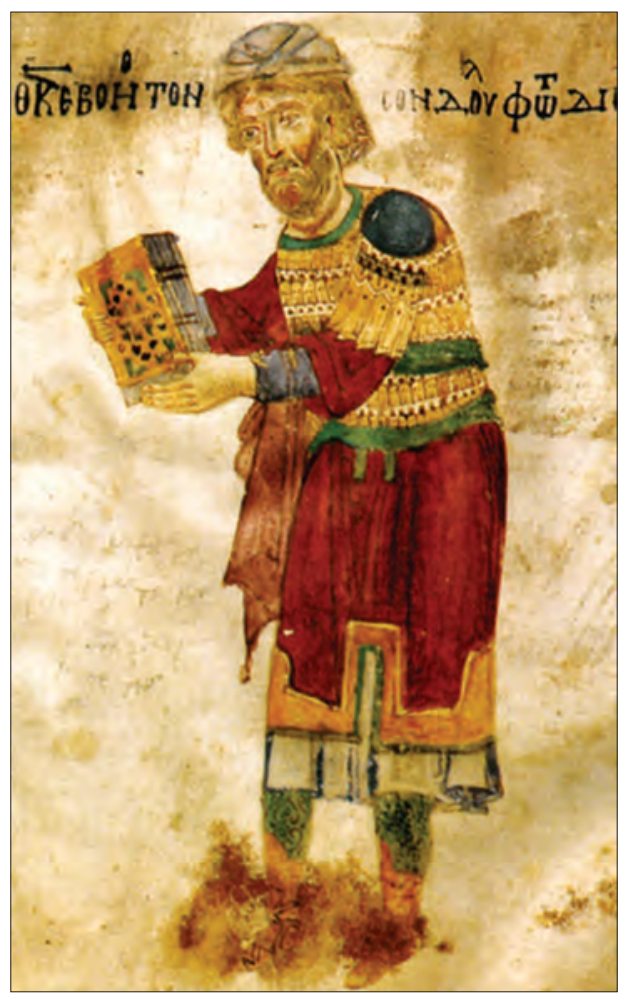

Fig. 19. Miniature "Hovhannis Protospatharius presents the Gospel to the Virgin" (1007) - Gospel of Adrianopolis, Mekhitarists library (Venice), Ms. 887, fol. 8, https://mycmsvs04.rrz.uni-hamburg.de/sfb950/content/IAA/browseColl.xml [30 IV 2019]. 


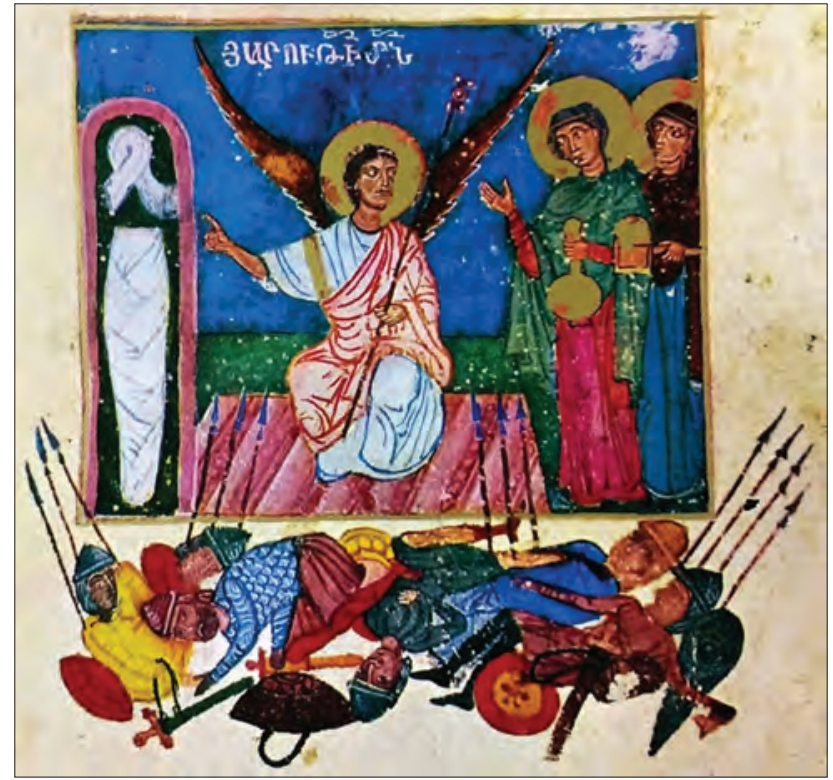

Fig. 20. Miniature “The resurrection of Christ" $\left(12^{\text {th }}\right.$ c.). - Gospel № 141/102, Mekhitarists library (Venice), fol. 77r. Author's photo [20 VIII 2019].

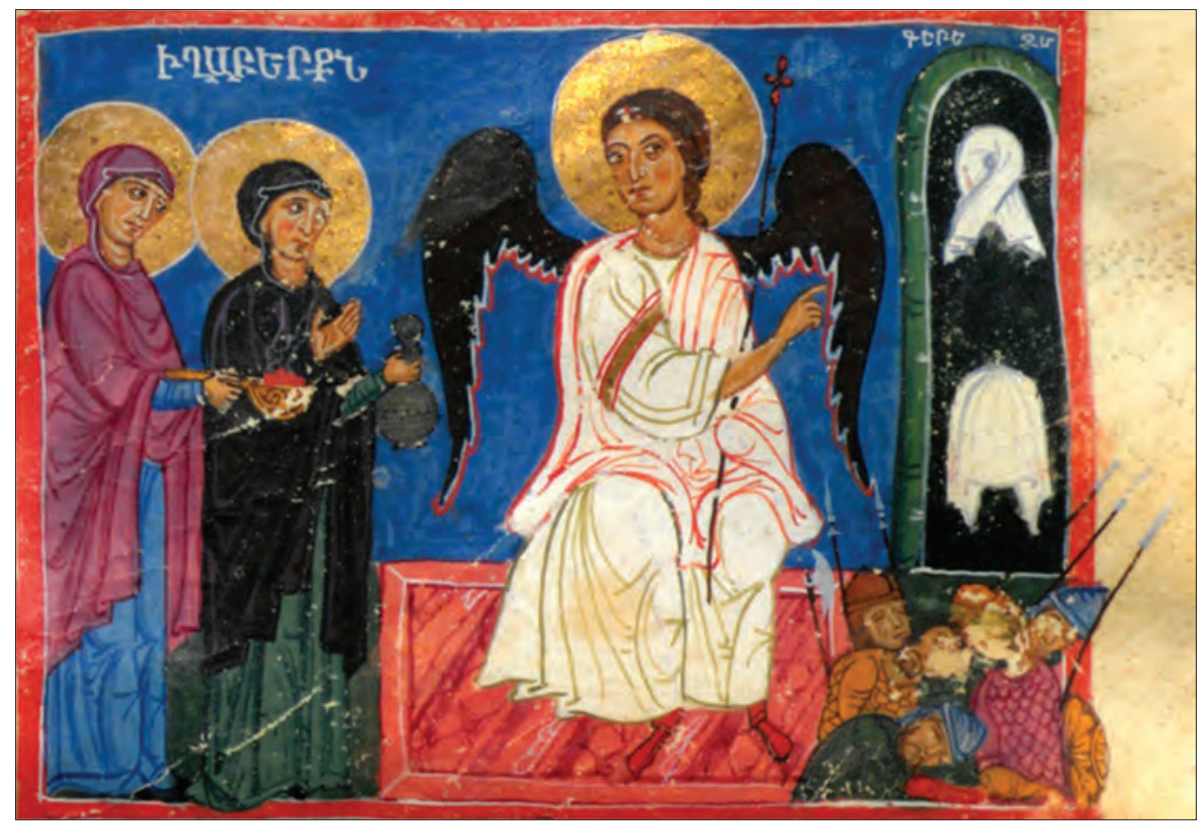

Fig. 21. Miniature "The resurrection of Christ" $\left(12^{\text {th }} \mathrm{c}.\right)$. - C. MARANCI, The Art of Armenia. An Introduction, Oxford 2018, fig. 4.3. 


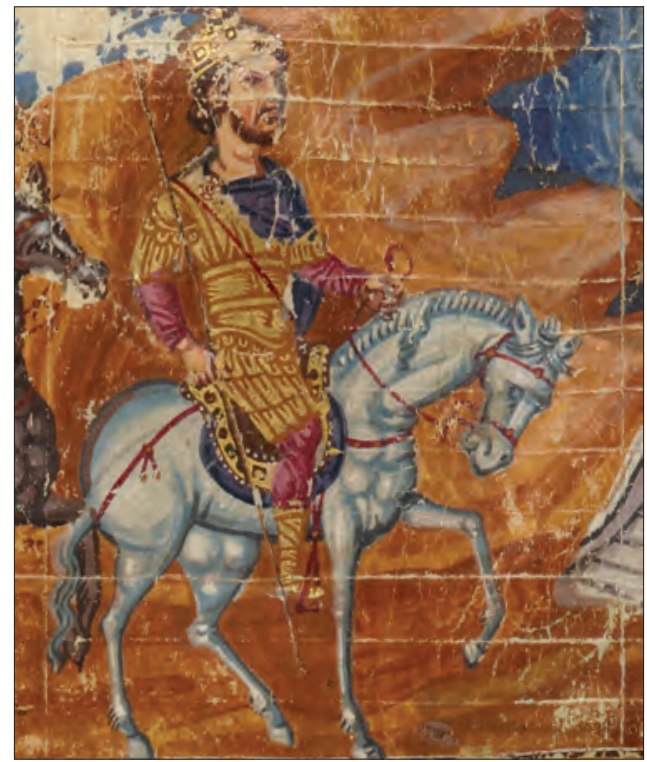

Fig. 22. Miniature "Emperor Julian the Apostate arrived to the city Ctesiphon on the Tiger” (Upper part), (879-883) - Homilies of St. Gregory of Nazianzus, National library of France, gr. 510, f. 830 (409v), https://gallica.bnf.fr/ark:/12148/btv1b84522082/f542. planchecontact [12 IX 2019].

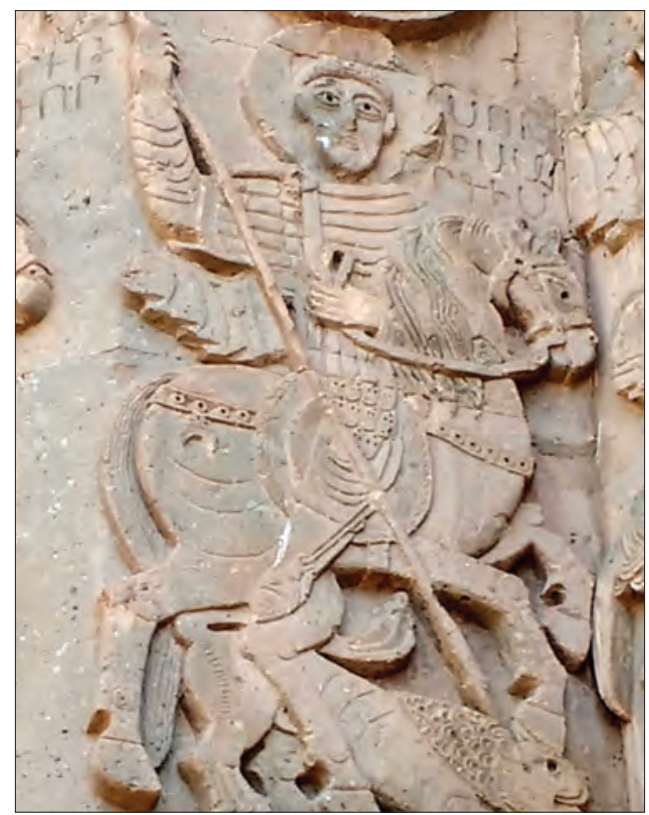

Fig. 23. St. Sargis's relief from The Cathedral of the Holy Cross, Aghtamar island (915921, modern Turkey) (in situ). Author's photo [20 VIII 2019]. 


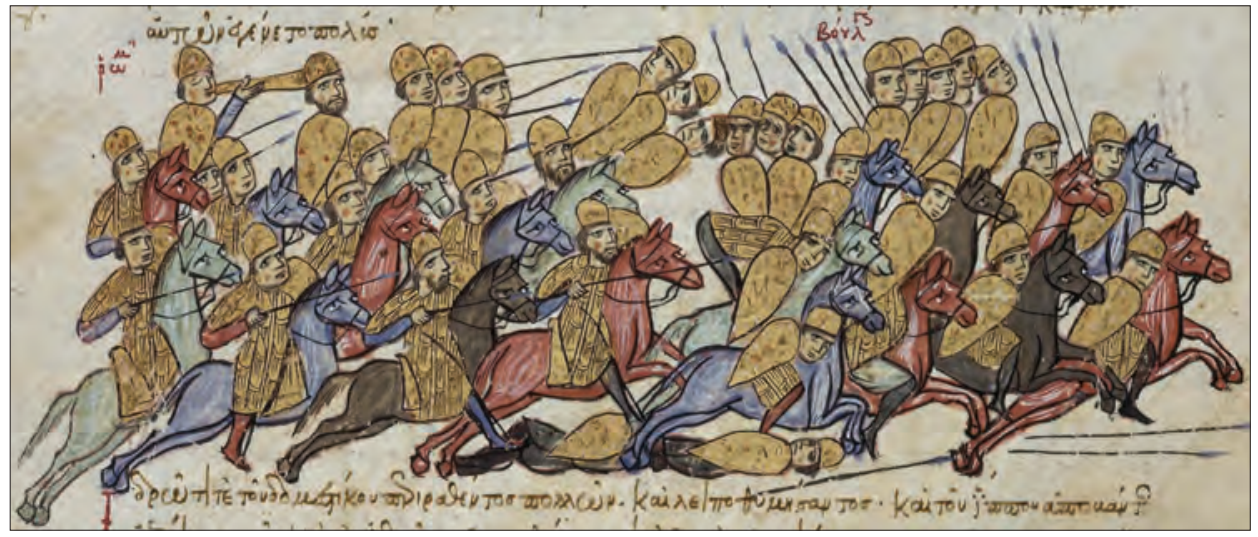

Fig. 24. Miniature "Tsar Simeon, pursued by the Hungarians, taking shelter in the stronghold of Drustra" (12 $2^{\text {th }}$ c.). - Madrid Skylitzes, National Library of Spain, ms. Graecus Vitr. 26-2, fol. 108v, http://bdh-rd.bne.es/viewer.vm?id=0000022766\&page=1 [12 IX 2019].

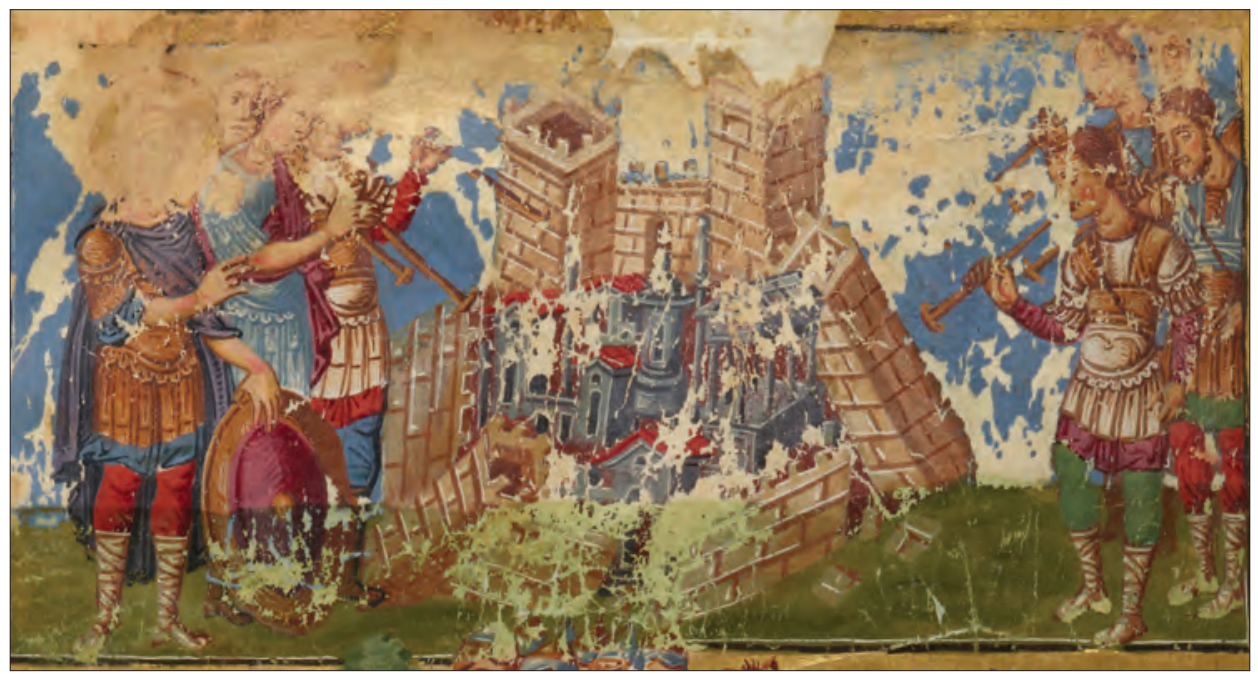

Fig. 25. Miniature "The fall of Jericho" (Upper part). Joshua (far left) and seven soldiers blowing the horns surround the crumbling walls of the city (879-883). - Homilies of St. Gregory of Nazianzus, National library of France, gr. 510, f. 860 (424v), https://gallica. bnf.fr/ark:/12148/btv1b84522082/f542.planchecontact [12 IX 2019]. 


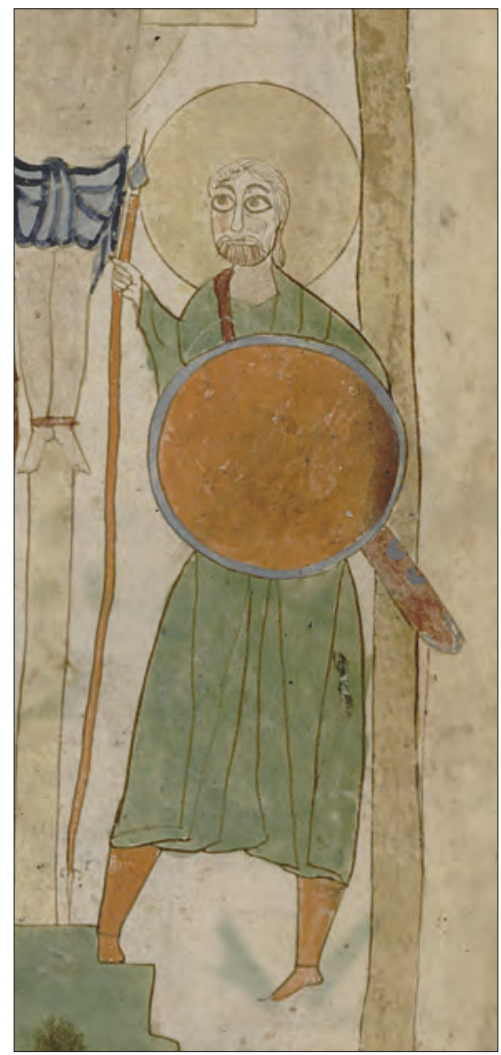

Fig. 26. Fragment of the miniature "Crucifixion" (1 $11^{\text {th }}$ c.). Author's photo [30 IX 2019].

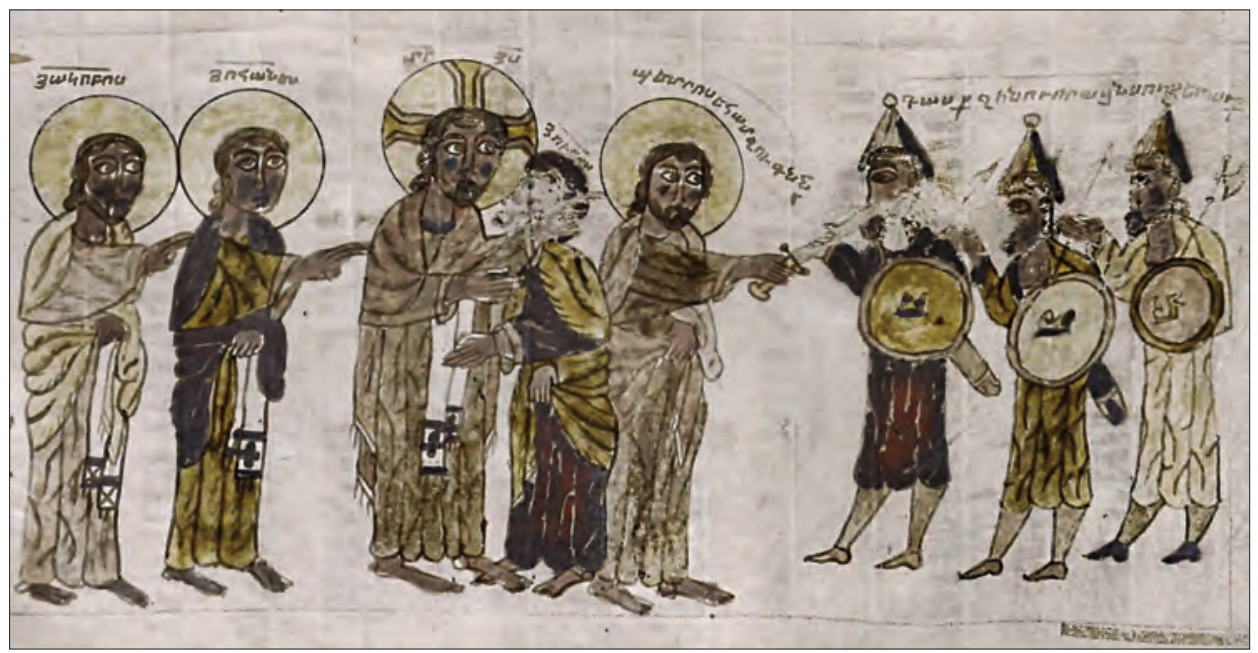

Fig. 27. Fragment of the miniature "Judas Kiss" (10 $10^{\text {th }}-11^{\text {th }}$ c.). Author's photo [30 IX 2019]. 


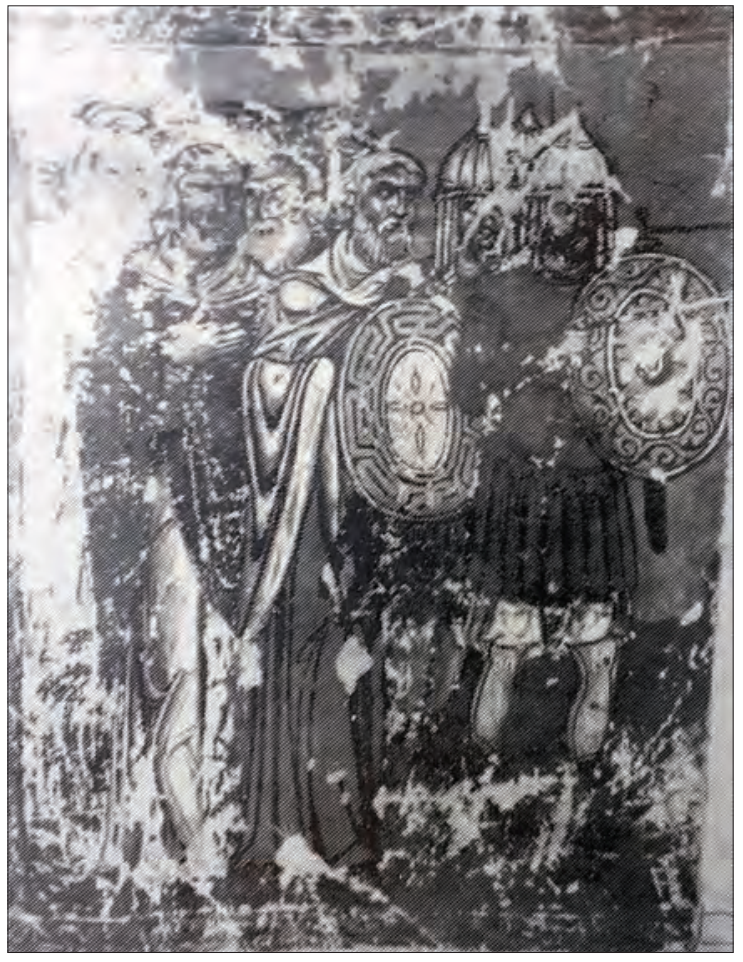

Fig. 28. Fragment of the miniature "Soldiers" $\left(11^{\text {th }}\right.$ c.). - Kars Gospel, Jerusalem Armenian Patriarchate, Ms. 2556, fol. 127. - S. Der Nersessian, L’Evangile du roi Gagik de Kars: Jérusalem No 2556, REArm 18, 1984, p. 92-93, fig. 10.

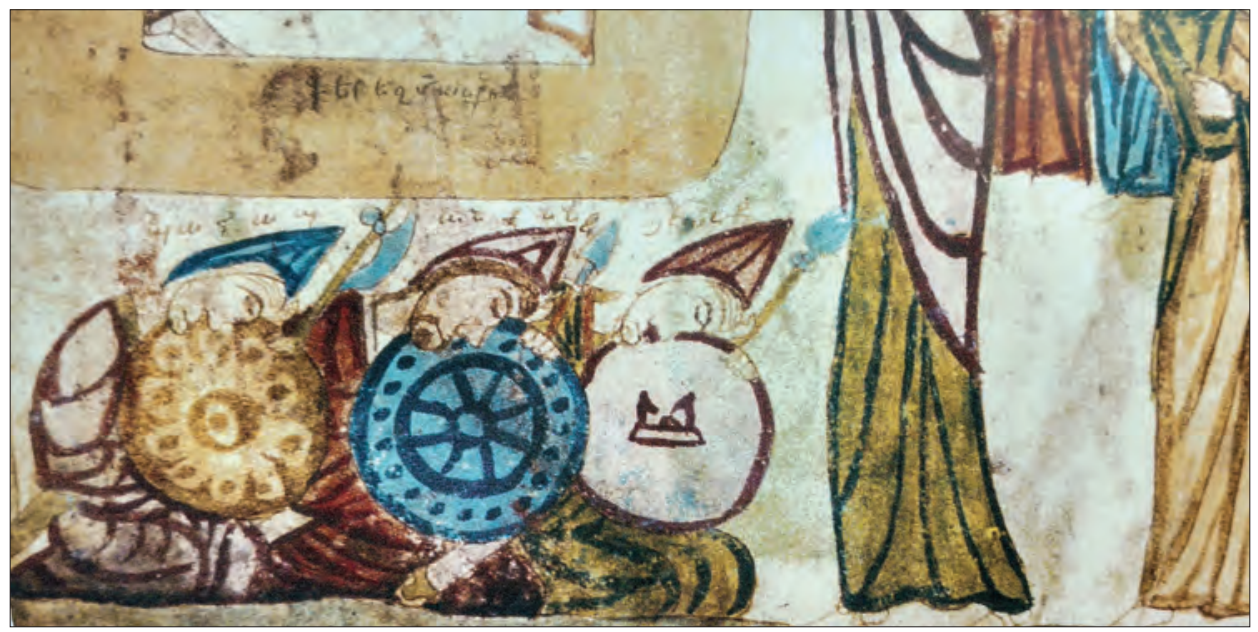

Fig. 29. Fragment of the miniature "Myrrhbearers", where armed Roman soldiers guarding the tomb of Christ (974). - Tsgrut Gospel, (Tsgrut village, Armenia), f. 9. - Н. Котанджян, Цгрутское Евангелие, Ереван 2006, p. 81. 


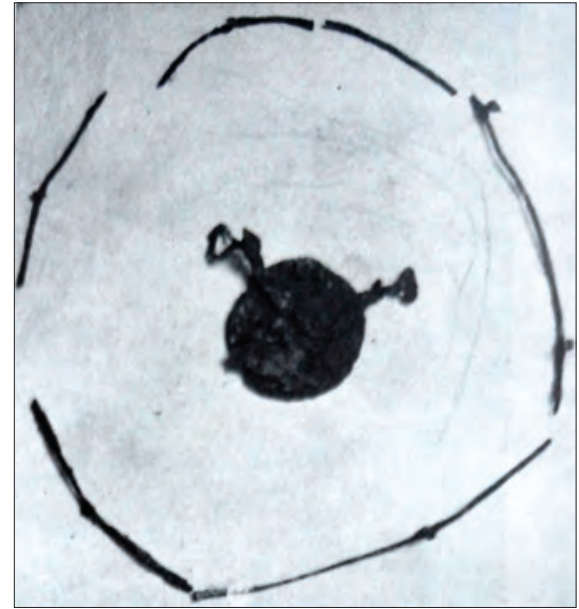

Fig. 30. Remains of the shield from Anberd $\left(7^{\text {th }}-13^{\text {th }}\right.$ c.? $)-$ U. <uคnFß3กFษ Gplıuu 1978, fig. 54.

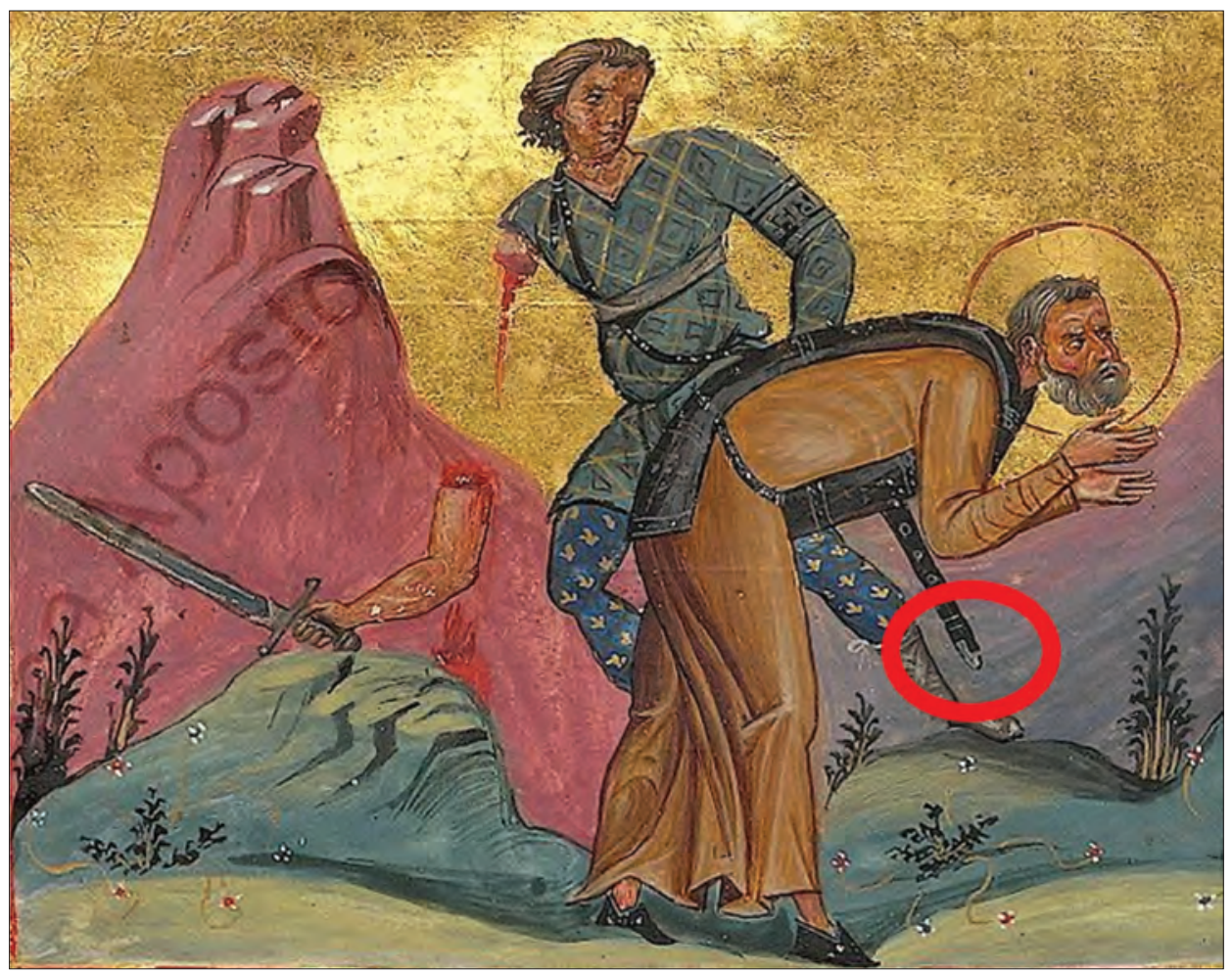

Fig. 31. Fragment of the miniature "St. Athenodorus Martyr" (end of $10^{\text {th }} \mathrm{c}$.). - Menologion of Basil II, Vatican library, Ms. Vat. gr. 1613, http://digi.vatlib.it/view/MSS_Vat.gr.1 613/0052? sid=a7590df9b8aca22111c8359533716419 [30 IV 2019]. 


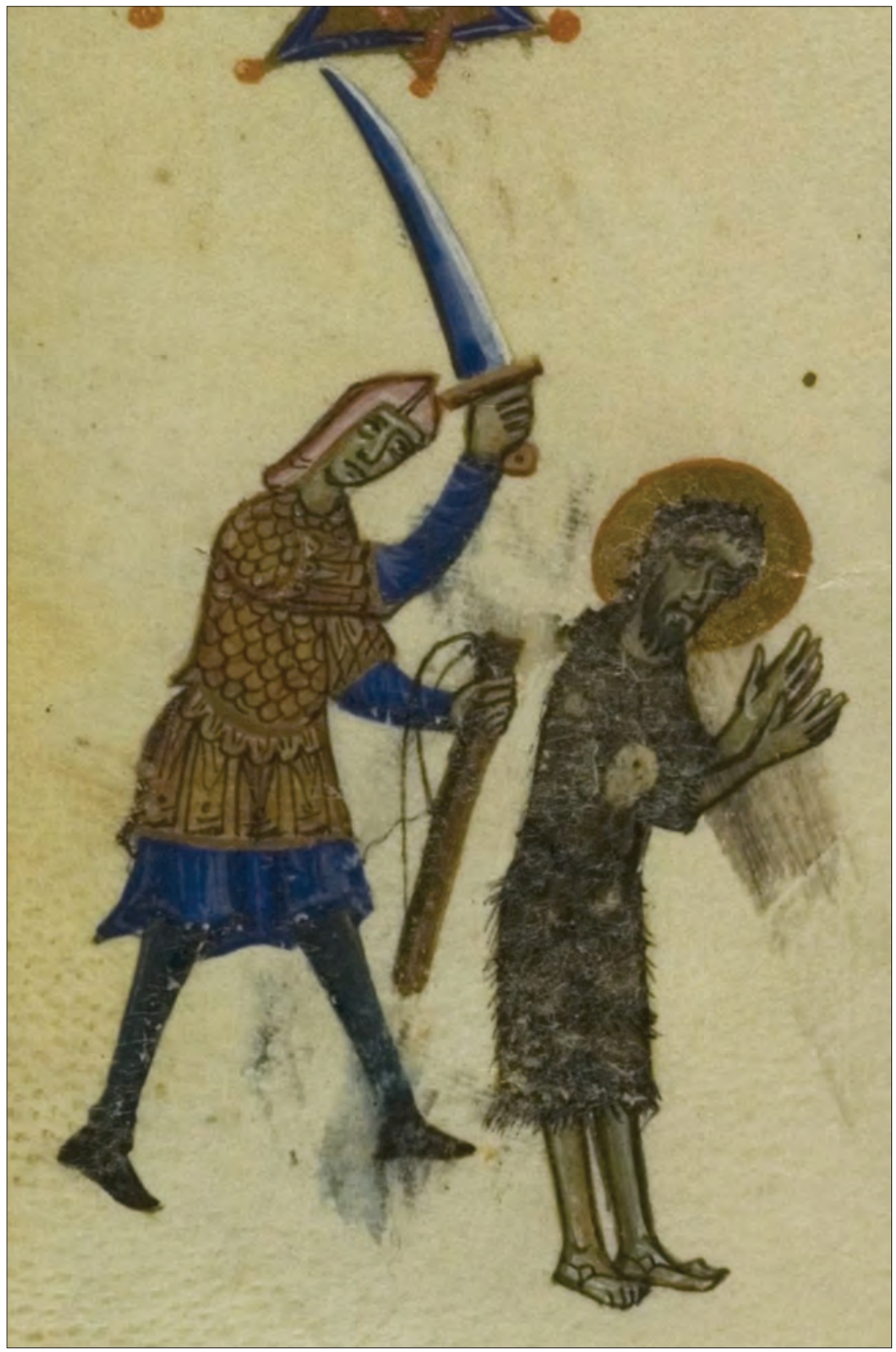

Fig. 32. Miniature "The Martyrdom of Cyprian of Carthage" (1198-1199). - Lviv Gospel, National library of Poland, Rps 8101 IIIS, 63v, https://polona.pl/item/ewangeliarz-zeskewry,NTU3NzE2OQ/127/\#item [30 IV 2019]. 


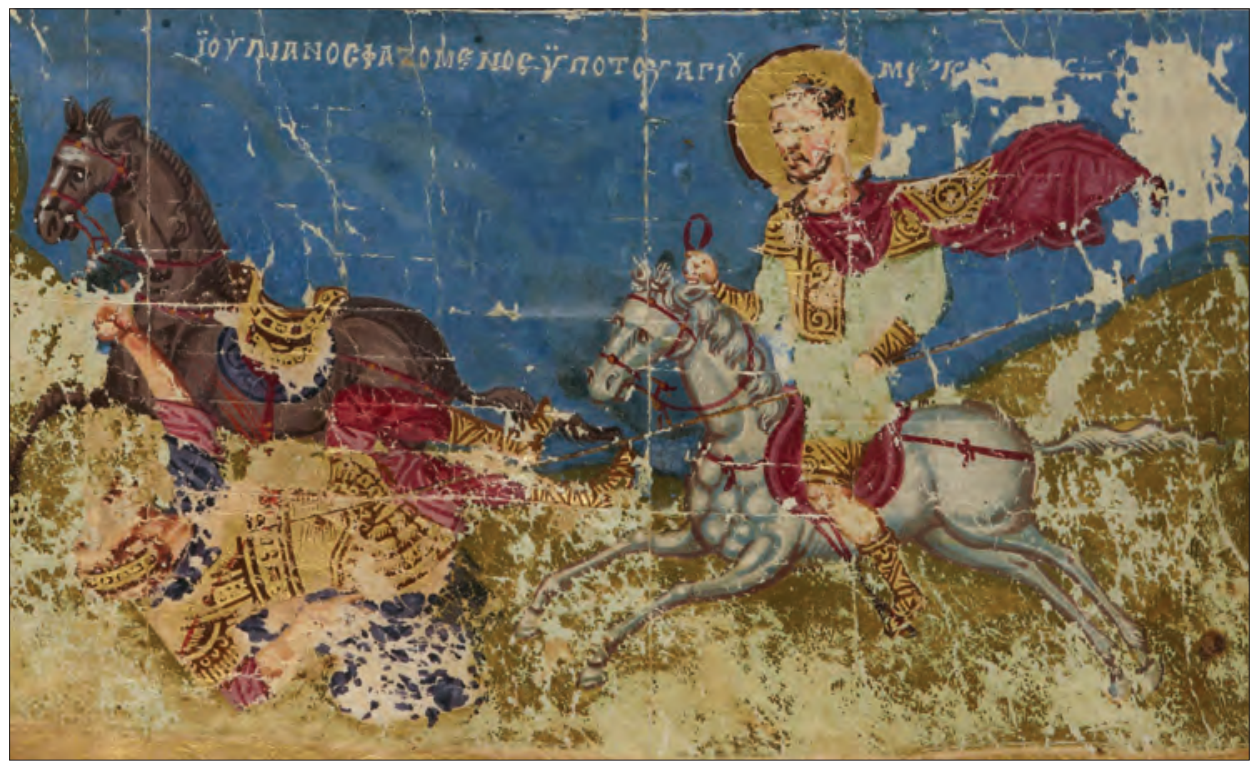

Fig. 33. Miniature "Julian's death: Julian, pursued by St. Mercuries, falls from his horse" (Lower part) (879-883) - Homilies of St. Gregory of Nazianzus, National library of France, gr. 510, f. 830 (409v), https://gallica.bnf.fr/ark:/12148/btv1b84522082/f542.planchecontact [12 IX 2019].

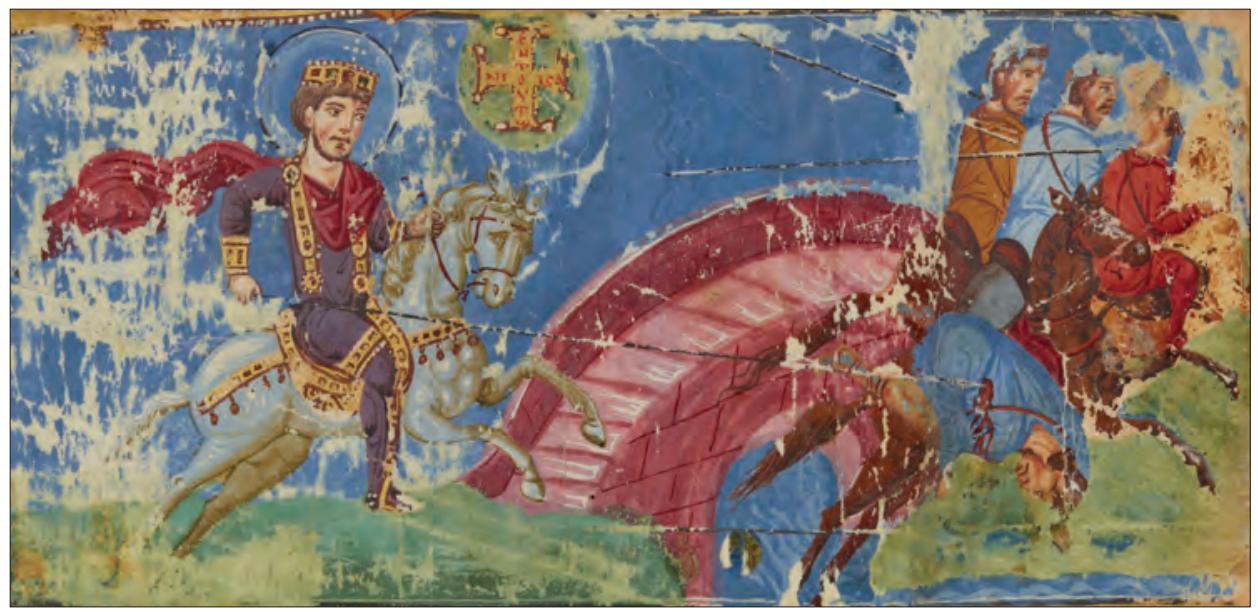

Fig. 34. Miniature "The Battle of the Milvian Bridge (312)" (Middle part), (879-883) - Homilies of St. Gregory of Nazianzus, National library of France, gr. 510, f. 891 (440r), https://gallica.bnf.fr/ark:/12148/btv1b84522082/f542.planchecontact [12 IX 2019]. 